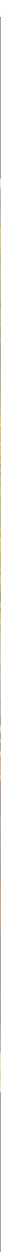

Secuencia final de Sunshine on Leith (2014), ante el edificio de la National Gallery de Edimburgo. Fotograma: Black Camel Pictures y DNA Films. 


\section{LA IMAGEN DEL MUSEO \\ EN EL CINE DE FICCIÓN}

THE IMAGE OF THE MUSEUM IN FILM

Resumen

Palabras clave

Abstract
José Manuel Estrada Lorenzo Bibliotecario y doctor en Historia del Arte por lo general, sus funciones de exposición, contemplación y aprendizaje. Muy lejos de la vida real, el museo aparece como un lugar ideal para siniestros asesinatos pero también como escenario de grandes robos, por ser almacén y contenedor de las grandes obras de la Humanidad. Sin embargo, algunas otras de sus funciones, como la divulgación, la restauración, la conservación o la investigación no suelen aparecer reflejadas en las películas, quizás porque resultan actividades necesarias para un museo, pero no del todo necesarias para el argumento de un film ambientado en un museo.

Museos, historia del cine, imagen del museo, funciones del museo.

Museums have often appeared in different films as a stage and generally highlighting their role as a place of exhibition, contemplation, and learning. As opposed to real life, the museum is shown as the ideal place for sinister murders as well as the scenario for grand heists since it is home of the greatest works of Humanity. However, some of its other functions -such as dissemination, restoration, conservation or research- are not usually featured in cinema, perhaps because though these are necessary activities for a museum, they are not entirely necessary for the plot of a film set in a museum.

Museums, History of Cinema, Museum Image, Museum Functions. 


\section{Introducción}

Sunshine on Leith (2014) es un film británico, basado en una obra musical de éxito en los escenarios londinenses, que narra el regreso de la guerra de Afganistán de dos jóvenes, Davy y Ally, a su ciudad natal, Edimburgo. Construida con el esquema habitual de chico conoce a chica (Davy conoce a Yvonne) y después pierde a chica, el joven protagonista decide recuperarla. Para ello, en una carrera vertiginosa por las calles de la ciudad, marcha en su busca y la encuentra en la explanada de la National Gallery, donde le declara sus intenciones a partir de la canción I'm gonna be (500 miles), del grupo escocés The Proclaimers, resolviéndose el film con el esperado final feliz. Esta secuencia musical, con decenas de extras bailando junto a sus protagonistas en los alrededores de la National Gallery, es la más representativa ilustración del papel del museo en el cine: un escenario, un plató. Cien años antes, el film mudo de Hitchcock Blackmail (1929) se clausuraba con una persecución del culpable por los tejados del British Museum. Entre ambos ejemplos, casi cien años de historia del cine, y una misma función cinematográfica.

El objetivo de este artículo es describir la imagen que el cine ofrece de una institución cultural como es el museo a partir de una serie de secuencias identificadas en el cine de ficción, en las que sus instalaciones adquieren protagonismo al convertirse sus cuatro paredes o sus fachadas en el marco de diferentes historias cinematográficas. La museología (León, 1988; Carbonell, 2005; Valdés Sagüés, 2008; Álvarez Domínguez, 2011) ha detallado desde sus orígenes cuáles son las funciones esenciales de un museo, funciones que se han ido transformando y adaptando a la vida contemporánea (Brown, 2018), según la sociedad y el ocio cultural se han ido también transformando. Buena parte de estas funciones han sido descritas y explicadas con criterios divulgativos por diferentes documentales, como por ejemplo $\mathrm{Na}$ tional Gallery (2014) (Le Genissel, 2015), en el que se define al museo como un lugar de conservación, de investigación, de preservación, de educación, y también de atracción turística. El cine documental, desde sus orígenes, ha servido para acercar al espectador las obras conservadas en las instituciones museísticas, sobre todo en tiempos pasados en los que no eran tan frecuentes los viajes turísticos como en la actualidad. Pero lo que se persigue con el presente artículo no es analizar según criterios del cine documental el papel del museo, sino hacerlo desde el punto de vista del cine no documental, del cine de ficción, como imagen de la representación del museo en la sociedad, descubriendo cuáles son las características y funciones principales de un museo a través de las propuestas de sus directores y guionistas.

A lo largo del siglo $\mathrm{xx}$, la imagen que el cine ha ofrecido del museo ha sido, sobre todo, la de una institución dedicada a la exhibición de importantes obras de arte, lugar de codicia de expertos ladrones atraídos por sus grandes obras e incluso como un lugar terrorífico donde pueden ocurrir los hechos más atroces. Pero no será hasta el siglo xxi cuando el cine se detenga a valorar el papel del museo como un gran contenedor de cultura, a considerar su defensa como una protección del patrimonio de un país y de toda una civilización y a enunciar los problemas cotidianos de la gestión museística. La imagen y las funciones del museo, desde el punto de vista cinematográfico, han ido evolucionando y acercándose a la idea moderna de museo, de tal modo que este ya no puede concebirse tan solo como un guardián de grandes obras como Las meninas o La Gioconda, sino que debe reflexionar sobre su papel en la vida contemporánea y ser un abanderado de la modernidad, como se propone en The Square (2017) el conservador Christian (Claes Bang) al 


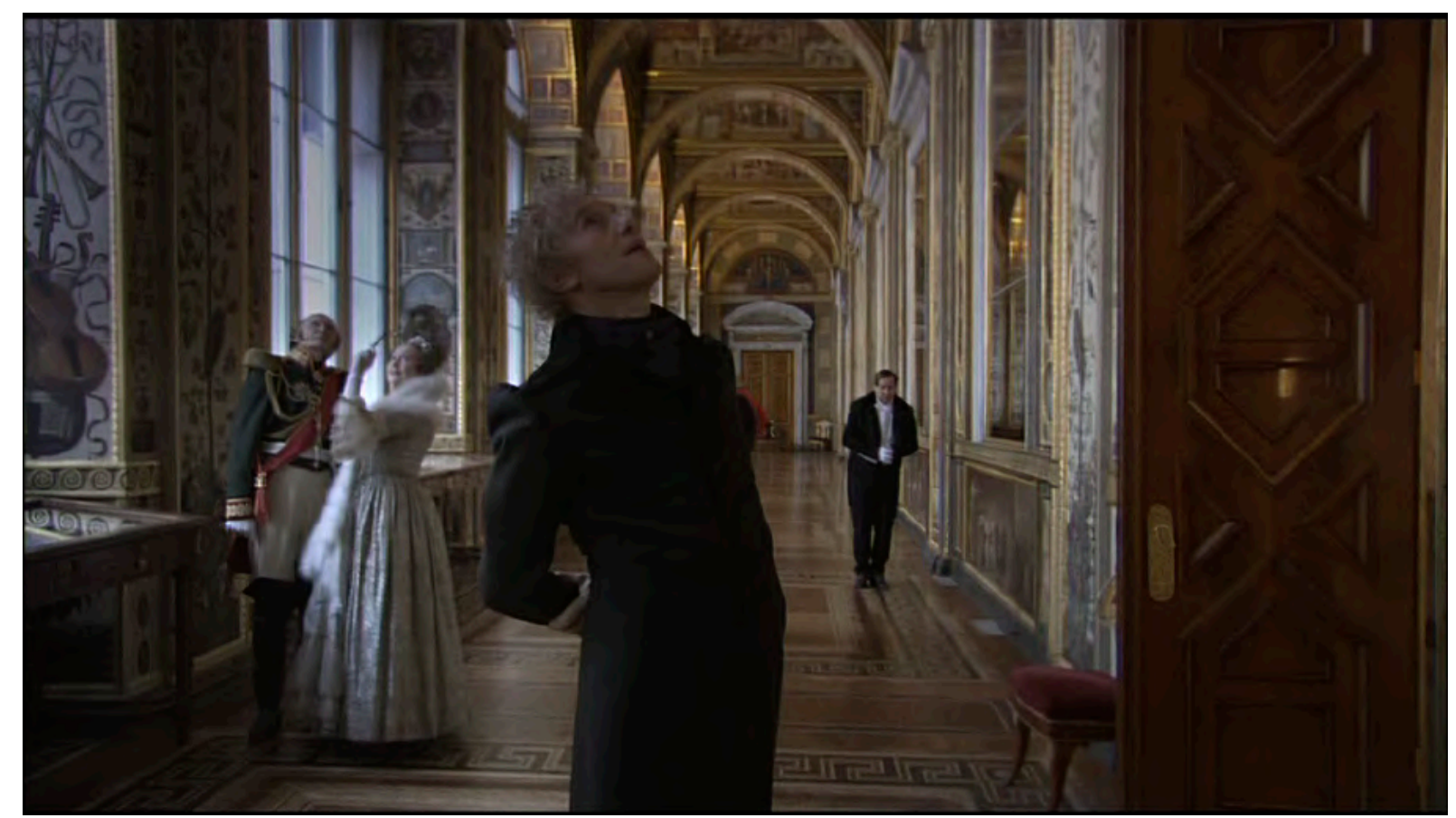

El marqués de Coustine, enseñando el Hermitage en Russkij Kovcheg (2002). Fotograma: The Hermitage Bridge Studio.

instalar en el patio del Museo de Arte Moderno de Estocolmo una instalación minimalista de neón -el cuadrado que da título al film-, aunque ello convierta a la institución en objeto de polémica (Casas, 2017).

Los films ambientados en museos no constituyen un género en sí, pues no tienen unas características comunes (como lo tienen el musical, el cine negro o la ciencia ficción), pero coinciden en el papel subsidiario del museo como un escenario cinematográfico. De un museo, interesan al cine sus exteriores (unas arquitecturas símbolo de prestigio para una ciudad o una nación) y sus interiores (sus salas de exposición, por donde circulan público y profesionales y contienen obras originales relevantes). Y en esos espacios transcurren historias relacionadas con personajes implicados en la vida del museo (público, artistas, guías, vigilantes, conservadores, copistas, ladrones...). Esta combinación de espacios, personajes e historias, en formato audiovisual, pone en valor el trabajo de los profesionales de un museo, señala la importancia de este tipo de institu- ciones en la vida contemporánea y permite identificar diferentes funciones esenciales a ojos de los cineastas, que en el fondo son las funciones asimiladas por el imaginario colectivo. En este sentido, el cine estaría más cerca de la imagen que el público y la sociedad tienen de un museo (exposición y enseñanza) que de la concepción que tienen sus profesionales (además de estas, investigación, gestión, restauración o divulgación).

\section{Un espacio para la exposición}

La función más evidente para los cineastas es la de una institución destinada a la exhibición de objetos dignos de ser expuestos, observados y estudiados con cierto detenimiento, a gusto de la paciencia de cada espectador. El museo acopia y recopila materiales, los clasifica y cataloga, los conserva, los almacena y expone los más relevantes con fines didácticos y estéticos (Caballero Zoreda, 1980). Las colecciones de un museo sintetizan, en su estricta selección de objetos de interés, la historia de un país, de 
un pueblo o de una cultura. El mejor ejemplo de un museo como un gran espacio para contener y conservar maravillas lo ofrece el film Russkij Kovcheg (2002), del director ruso Aleksandr Sokúrov. Su personaje principal es un diplomático francés del siglo XVIII, el marqués de Coustine, que va deambulando por las diferentes estancias del Museo del Hermitage (antiguo Palacio de Invierno de los zares). Este va desvelando al espectador las múltiples obras que encierran sus paredes mientras rememora la historia y la vida en la corte rusa en un único plano secuencia de hora y media. Ante los ojos del espectador van desfilando, sin orden cronológico, la Rusia zarista de Pedro I, Catalina la Grande y Nicolás II, la Segunda Guerra Mundial o la época estalinista, para llegar a la secuencia final del film donde el museo, semejando una gran arca que surca los mares con toda la cultura rusa en su interior, avanza hacia el futuro, ya que, como señala el narrador, el arte hace inmortal al hombre: «estamos destinados a navegar eternamente... a vivir eternamente» (Latorre, 2007).

El propio Sokúrov volverá a indagar sobre el papel del museo, en este caso ejemplificado en el del Louvre («El Louvre, el Louvre, ¿no será que este museo vale más que toda Francia?», se pregunta el director en un momento del film), en su película Francofonia (2015). En ella se narra el encuentro entre Jacques Jaujard, a la sazón conservador del museo durante la Segunda Guerra Mundial, y el militar nazi Franz Wolff Metternich, a quien se encargó la misión de proteger el Louvre durante los años de la ocupación alemana (Casas, 2016). En este film se mezclan imágenes de archivo con otras de ficción protagonizadas por estos dos personajes para trascender la importancia universal del propio museo y reflexionar sobre la conservación y propiedad del patrimonio artístico.

Las instituciones museísticas no son solo espacios agregadores de épocas, culturas y estilos, sino también espacios más monográficos, donde exponer y recordar la existencia y la obra de un único artista, a través de la presentación más o menos organizada de sus obras, con el objetivo de darlas a conocer a las futuras generaciones. La intención del marchante Theo Van Gogh, según se narra en una de las secuencias finales del film Vincent and Theo (1990), es la de crear en su propia casa un museo donde exponer los cuadros $y$ dibujos que su hermano Vincent le fue enviando durante años y que aún son desconocidos para el gran público:

Es una serie de habitaciones, como un museo o
una galería... Es solo un sitio donde pueda venir
la gente, donde la gente que quiera pueda venir a
ver lo que hizo. Mirar sus cuadros. Eso es lo que es
una galería... Esto es lo más importante. Esto es lo
más importante de mi vida.

Esta secuencia no es solo un homenaje de Theo hacia Vincent, sino también del director del film Robert Altman hacia quienes, con su espíritu visionario e impulso, han contribuido a la creación de espacios y colecciones museísticas que han evitado la pérdida o dispersión de las obras de arte y contribuido a su conocimiento, preservación y exhibición.

Como exposición ordenada y lógica de las obras más reseñables, las salas de un museo son lugares propicios para la reflexión y para el análisis estético. La contemplación de obras de diferentes épocas invita a la comparación y hace aflorar añoranzas y nostalgias por pasados tiempos mejores, que a su vez revalorizan el papel del museo como salvaguarda de la cultura. Así le ocurre al poeta Eumolpo cuando, en compañía del joven Encolpio, visita un museo de arte en el film Fellini-Satyricon (1969):

Las obras maestras que ves en esta pinacoteca -le dice Eumolpo a Encolpio- delatan el actual letargo. Pinturas así nadie sabe plasmarlas hoy. ¿Y por qué ha sido provocada esta revolución? Por la avidez de dinero. Tiempo atrás el ideal de los hom- 
bres era la virtud pura y simple y por ello florecían las artes... Ah, no te sorprendas, joven amigo, de que la pintura esté acabada. Ya que es más bello a nuestros ojos un montón de oro que todas las obras de Apeles y Fidias.

Esta pinacoteca «felliniana» es toda una obra maestra de reinterpretación de la antigüedad clásica y un hallazgo de los responsables de la dirección artística de este film (Danilo Donati y Luigi Scaccianoce). Este museo que visitan Eumolpo y Encolpio no está recreado con criterios de una colección de obras de arte de la antigua Roma, sino al estilo del concepto contemporáneo de museo, de tal forma que pinturas y cuadros cuelgan de las paredes o se apoyan en ellas, algunos sin marcos y otros con los bordes semidestruidos, pues el tiempo ha hecho mella en ellos, y en algunos se observan las huellas evidentes de la intervención de los restauradores; además, como en los tiempos actuales, es visitado por grupos de turistas que intentan, a gran velocidad, saborear entre sus salas las grandes obras del pasado.

Sin embargo, este valor del museo como ese espacio presentado en el Fellini-Satyricon (1969), donde el tiempo se ha detenido y solo alberga obras producidas en un pasado remoto, es lo que algunos artistas critican, ya que esta veneración de lo pretérito resulta contrapuesta a la idea de un arte moderno, vivo y actual por el que debe de abogar todo artista vivo. Reunidos varios pintores en un café de París (Moulin Rouge, 1952), uno de ellos, Georges Seurat (Christopher Lee), les propone a los demás visitar ese día el Museo del Louvre justo en el momento en que se incorpora a la tertulia el pintor Toulouse-Lautrec (José Ferrer): «Tómate un coñac, Henri, y luego iremos al Louvre a confortar nuestro espíritu». Esta propuesta no es del agrado del recién llegado, como refleja su instintivo comentario: «El Louvre, ese cementerio».

La escritora polaca Sophie Brzeska, compañera sentimental del escultor vanguardista
Henri Gaudier, comparte en Savage Messiah (1972) este aspecto negativo del museo como almacén del arte pretérito al opinar que el Louvre no es más que «una ostentosa casa repleta de basuras». Basa su opinión en la idea de que «el arte de hoy ha de nacer de algo actual», señalando con ello el carácter anacrónico y polvoriento de este tipo de instituciones. El escultor Gaudier, muy al contrario, piensa que el Museo del Louvre tiene valor precisamente por ser una cadena transmisora del conocimiento, ya que «el arte nace del arte», y por ello pregunta a Sophie: «¿De dónde crees que proviene la actualidad?». Él mismo contesta: «No existe una separación clara entre el mundo de hoy y las civilizaciones antiguas». Esa línea continua de estilos y obras de distintas épocas es lo que convierte a los museos en centros indispensables para conocer la historia de la cultura y, en consecuencia, para el aprendizaje y enriquecimiento personal de las nuevas generaciones. Ambas opiniones no hacen sino reforzar la dicotomía que preside la filosofía de un museo en época contemporánea: salvaguardar las obras del pasado como defensa del patrimonio y como objeto de deleite, estudio y reflexión de los ciudadanos, pero a su vez ofrecer una imagen más actual del mismo a través de nuevas lecturas, nuevas fórmulas expositivas y nuevas ordenaciones de las colecciones que lo hagan atractivo a los más jóvenes y a los nuevos visitantes (Guasch, 2008).

El protagonista de The Square (2017), comisario y conservador de un museo de arte contemporáneo sueco, llega a interrogarse en un momento del film por la función de un museo moderno cuando una periodista le pregunta cuál es el reto de dirigir uno. Él responde que el dinero. Un dinero que permite crear exposiciones y adquirir importantes piezas. $\mathrm{Y}$ cuando ella prosigue indagando sobre la definición de lo que debe o no exhibirse en un 


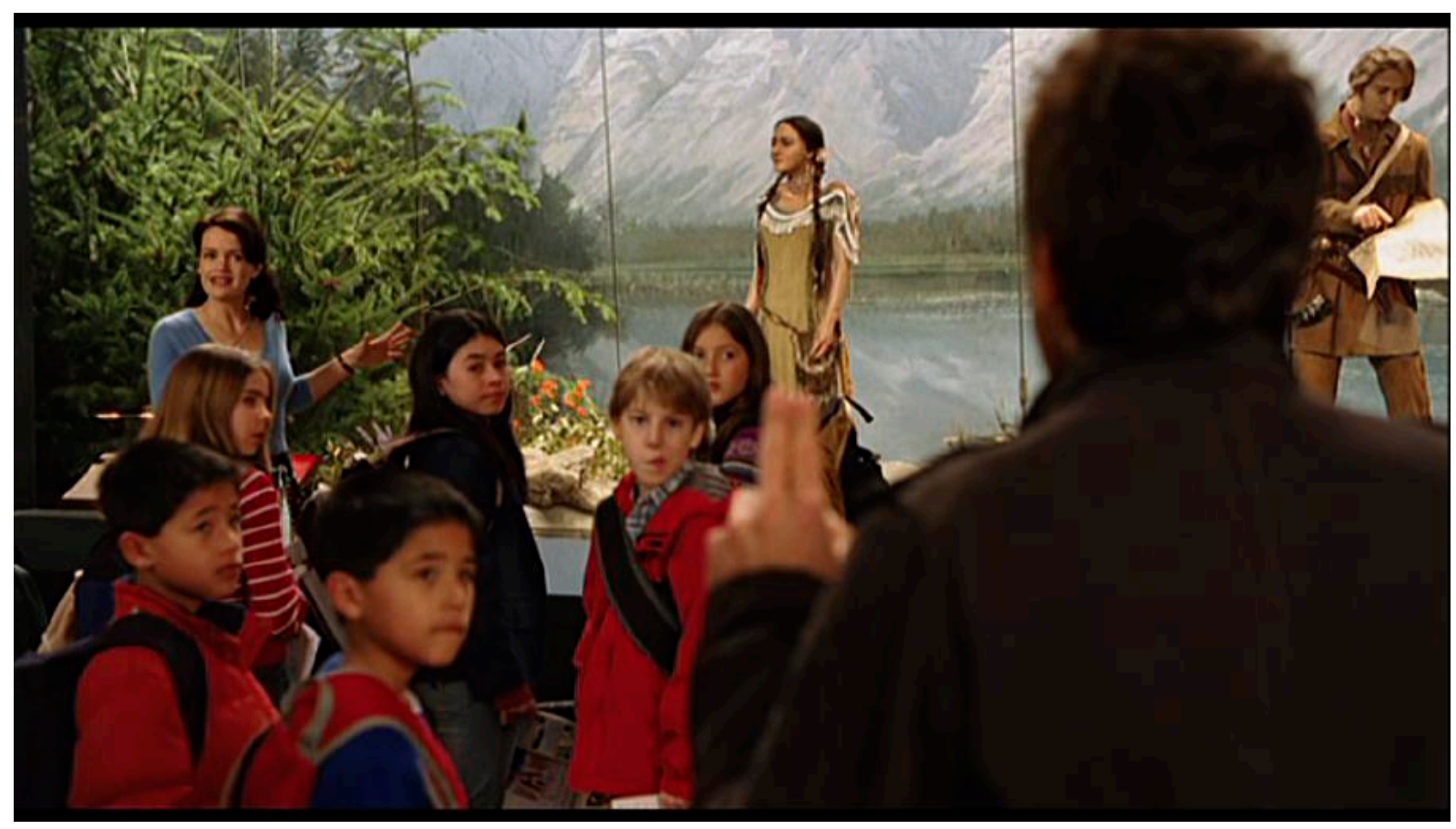

Rebecca Hutman, la guía del Museo de Historia Natural de Nueva York, enseñando sus salas a unos niños en Night at the Museum (2006). Fotograma: 20th Century Fox.

museo, el comisario termina preguntándole si todo lo que se exhibe en un museo es arte: «Si pusiéramos tu bolso aquí, ¿eso lo convertiría en arte?». Este film, además de reflexionar sobre la idea del arte en el mundo actual, critica el elitismo de algunas instituciones culturales, que aunque quieren vivir de cara a la sociedad, viven de espaldas a ella, como le ocurre a su protagonista, centrado en su trabajo en el museo y alejado de la realidad hasta que el robo de su móvil le hace descender a ella. Esta es una postura museística opuesta al populismo, del que es partidario el escultor de House of Wax (1953) cuando, destruido su primer museo, lo rehace de sus cenizas con un planteamiento distinto, ofrecer al público lo que el público desea ver:

Estoy volviendo a construir mi exposición desde el principio. Ahora voy a darle al público lo que le gusta. Emociones. Truculencia. Horrores. Así, todo el mundo cuando salga de aquí irá a contarles a sus amigos lo maravilloso que es morirse de miedo. (...) Los crímenes más violentos serán reproducidos en cera y exhibidos mientras todavía estén frescos en la mente del público.

Dos planteamientos contrapuestos que pueden resumir dos de las tendencias actuales de los museos: grandes exposiciones estrella para todos los públicos que llenen las salas o exposiciones especializadas que atraigan a un público no tan mayoritario y más especializado.

\section{Un espacio para el deleite y el aprendizaje}

Un museo es, como resume el pintor Marcelo (Antonio Ferrandis) en Yo soy fulana de tal (1975), un lugar para «experimentar elevadas emociones espirituales» y las obras que en ellos se exhiben, como señala Henri Gaudier en Savage Messiah (1972), se encuentran allí para ser disfrutadas. Subido en lo alto de un moái de la Isla de Pascua, el escultor arenga a los visitantes del Louvre en contra de la 


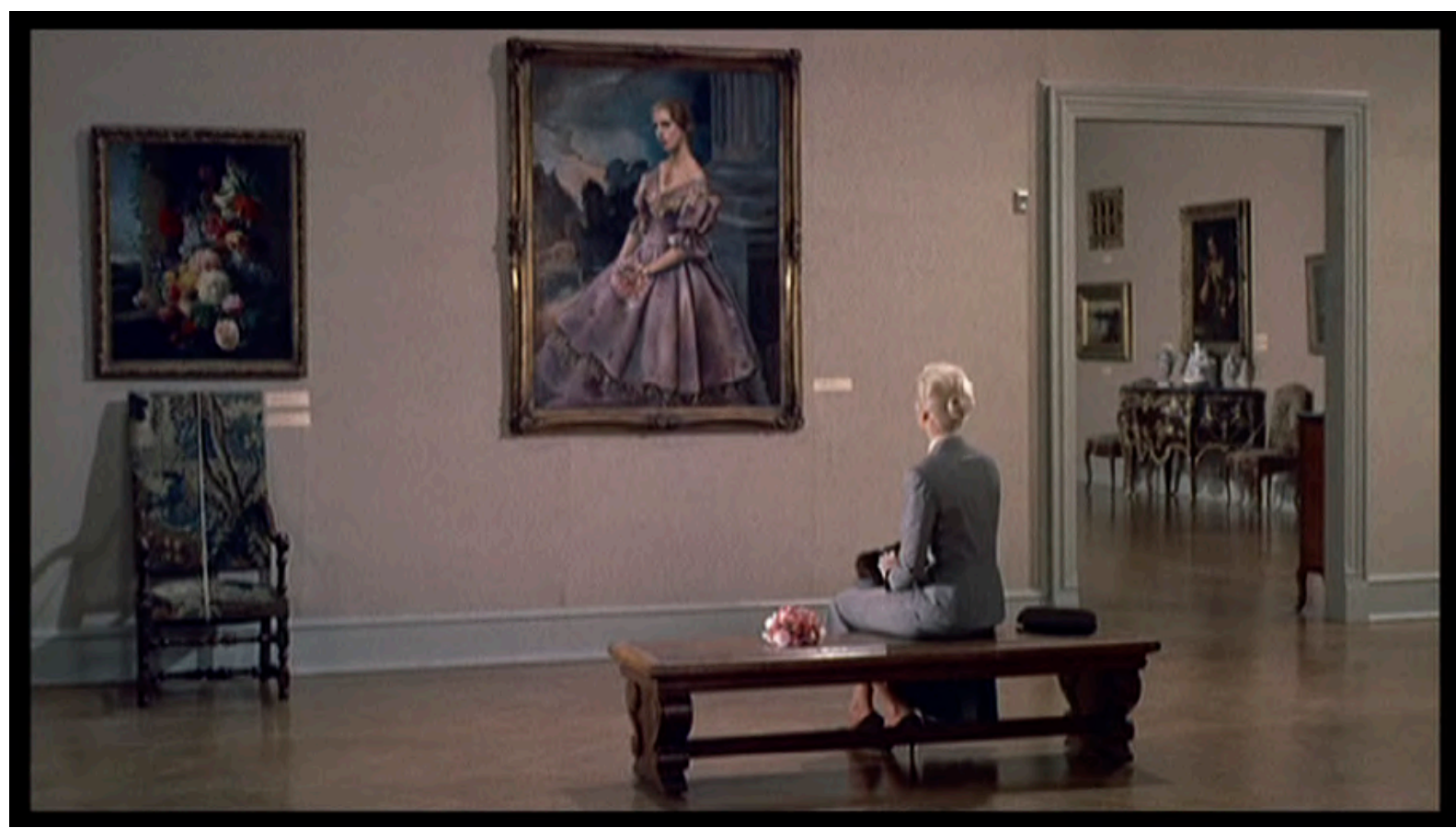

Madeleine, contemplando un retrato en el Museo de Bellas Artes de San Francisco en Vertigo (1958). Fotograma: Paramount Pictures.

sacralización del arte y en favor de un goce sensorial: «El arte tiene vida. ¡Disfrútenlo! Ámenlo u ódienlo, pero no, no lo veneren». Una llamada de atención que, pronunciada por un artista tan poco convencional como este joven escultor, esconde también una velada crítica del propio director, Ken Russell, al culto moderno hacia la obra fetiche, que ha convertido las visitas a los museos en una carrera por ver in situ sus obras más emblemáticas, pero sin detenerse un tiempo a disfrutarlas.

Es un hecho que, pese a estos comentarios que no rechazan en el fondo la idea de museo, sino que preconizan su reconversión hacia la modernidad, la exhibición es una primordial función de estas instituciones. De hecho, los museos del mundo, y especialmente los de arte, son visitados a diario por cientos de personas que se detienen ante los trazos, los colores y las formas de pinturas, esculturas y objetos, cautivándoles sus sentidos en una infinita recreación del síndrome de Stendhal. Este afán contemplativo lo repite periódicamente Madeleine (Kim Novak), la protagonista de Vertigo (1958), en una de las salas de un museo de San Francisco ante el retrato de una joven de especial peinado helicoidal, aunque luego se desvelará que su contemplación intencionada es parte de una estratagema en la que caerá involucrado un antiguo expolicía (James Stewart). También se detienen contemplativos los visitantes del museo que se recoge en el episodio The Picture de la película Three Cases of Murder (1955), en cuyas paredes cuelga un siniestro paisaje obra de un misterioso pintor, Mr. X. Ante esta enigmática pintura un «erudito» visitante se atreve a emular a los expertos empleando un lenguaje pretencioso y hueco: «Sí, es muy interesante. Es evidente que está influido por Constable, pero en todo ello flota la horrible y álgida frialdad del vacío». Una crítica evidente y fácil del director hacia expertos y críticos superfluos. 


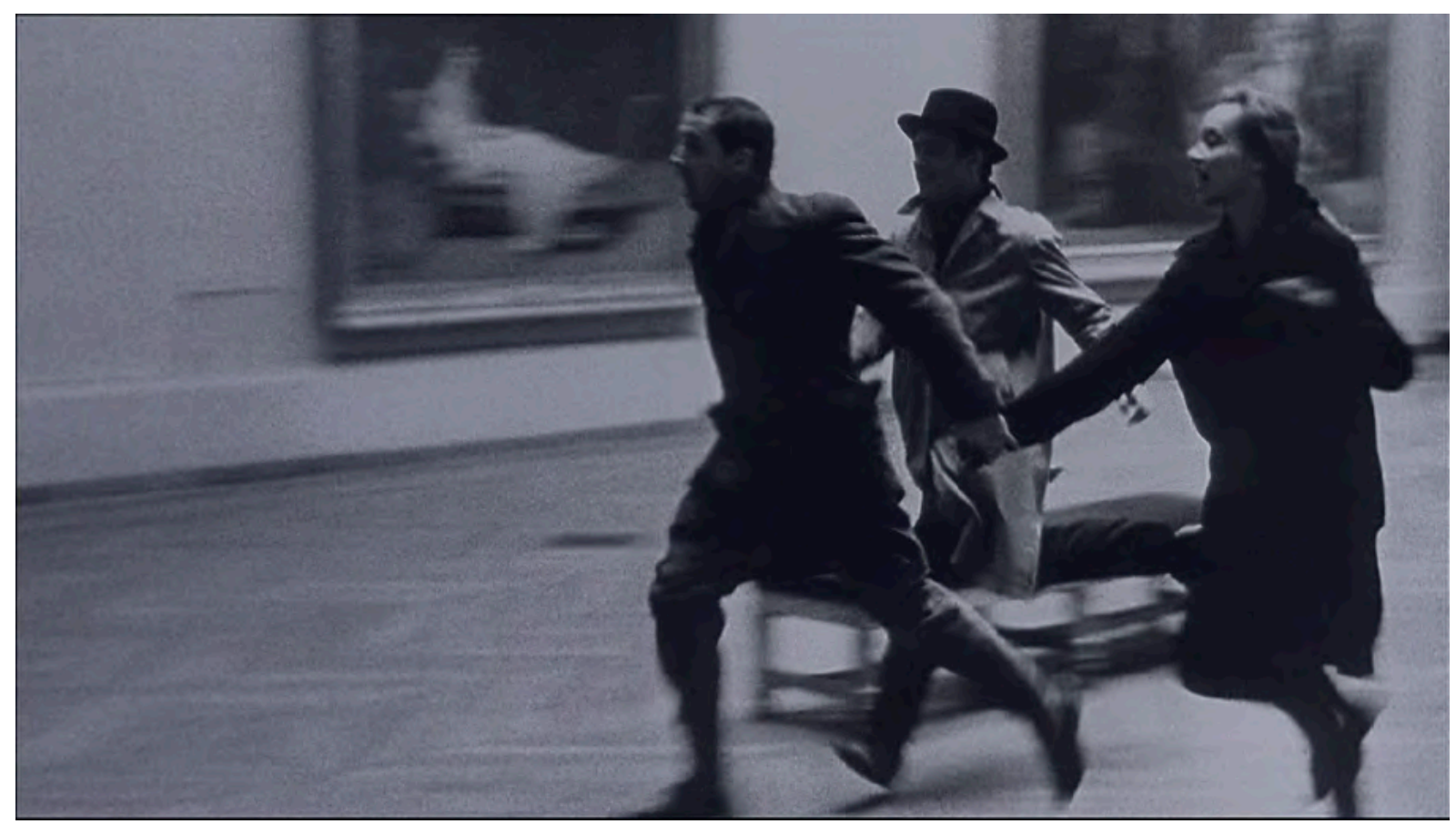

Los tres protagonistas de Bande à part (1964), cruzando el Louvre en un tiempo récord. Fotograma: Columbia Pictures.

Otros visitantes, en cambio, como los tres protagonistas de Bande à part (1964), no se detienen ni un minuto frente a las obras de arte -en este caso las del Louvre-, sino que las recorren como una exhalación intentando superar el récord de un norteamericano que visitó el museo en nueve minutos, con el enfado de uno de los vigilantes, que les recrimina que con sus carreras molestan a los visitantes. Una brevísima secuencia que refuerza la idea de que un museo no tiene por qué ser un lugar soso ni aburrido (esta escena fue homenajeada años después en el film de Bertolucci The Dreamers, 2003).

$\mathrm{Su}$ característica condición de contenedor de obras de gran belleza, de grandes obras maestras y originales, convierte al museo en un lugar idóneo para la enseñanza y el aprendizaje en directo (Falk, 2007).

Pasen, pasen, señoras y caballeros. Visiten nuestro museo. Vean la cámara de horrores. (...)
Vean y admiren el mundo de cera, el umbral de la fama, la cámara de los horrores. Una exposición cultural que les instruirá y emocionará al mismo tiempo.

Proclama un animador para atraer al público a las puertas del museo de House of Wax (1953). En este ejemplo, un pequeño museo de figuras de cera, sus visitantes pueden añadir, al deleite de la contemplación, el aprendizaje histórico pues las figuras de cera, con una clara finalidad didáctica, recrean famosos episodios de la historia universal (Marco Antonio y Cleopatra, Lincoln, María Antonieta, Juana de Arco...). En el film Mona Lisa Smile (2003), la nueva y progresista profesora de una conservadora y elitista universidad norteamericana solo para mujeres (Katherine Ann Watson, interpretada por Julia Roberts) lleva a sus alumnas a un museo para darles clase en una relación más en vivo con el arte que las diarias diapositivas del proyector del aula. Esta esce- 


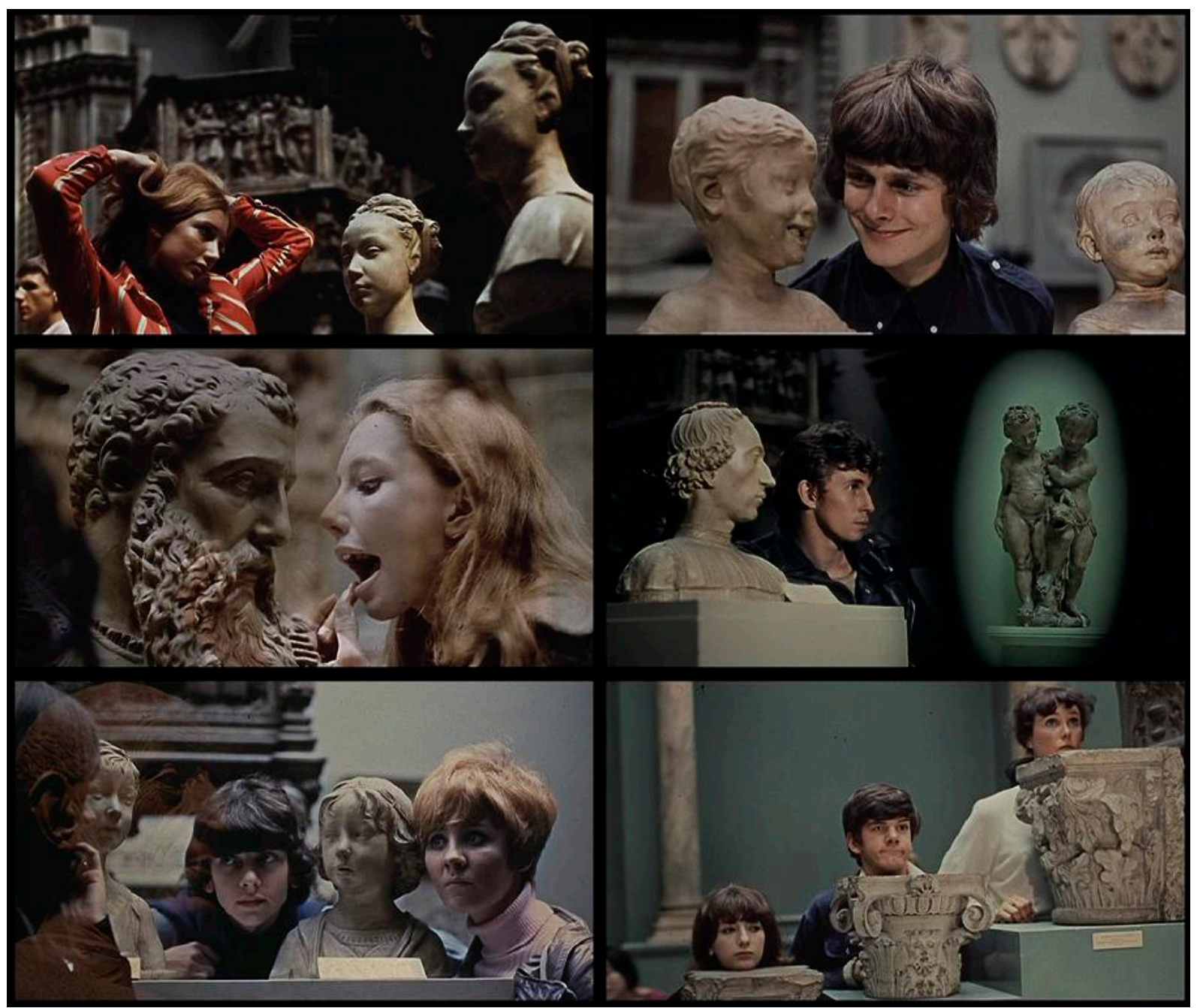

Los alumnos del profesor Thackeray, de To Sir, with Love (1967), visitando el British Museum. Fotograma: Columbia Pictures.

na transmite otro carácter indisoluble a la noción de museo: la posibilidad de contemplar las obras originales sin el intermedio de una copia, reproducción o fotografía (Almagro Gorbea, 1988). En To Sir, with Love (1967), el profesor Mark Thackeray (Sidney Poitier), que trabaja en una complicada escuela de los suburbios de Londres, decide realizar con sus alumnos una visita al British Museum -que para muchos de ellos posiblemente sea la única que hagan en su vida- no solo para enseñarles arte, sino también para intentar abrir sus mentes y sus sentidos ante la contemplación de las obras del museo. Esta secuencia, construida como una sucesión de imágenes, divertidas y simpáticas, de los alumnos junto a esculturas y pinturas (ofreciendo interesantes contrastes o similitudes entre los visitantes y las obras expuestas), adopta un estilo de cine documental, el cual sirve para mostrar el efecto de la visita en los jóvenes estudiantes y, a su vez, recalcar el prestigio e importancia de una institución como el British Museum.

Así, el museo cumple con otra de sus funciones principales, formar al público (Arriaga, 2011) en conocimientos, interpretación y estética, trascendiendo desde su pasado a la actualidad y contribuyendo a forjar una sociedad 
más y mejor instruida. Un aprendizaje que no solo recae en docentes, como lo son Thackeray y Watson, sino también en los propios artistas, cuya mirada experta ofrece otro punto de vista: la joven Lee (Barbara Hershey), amante de un pintor mucho mayor que ella, Frederick (Max von Sydow), en Hannah and Her Sisters (1986) celebra ante sus hermanas poder visitar un museo en su compañía: «Oh, fuimos a la exposición de Caravaggio en el Met. Es una gozada ir a un museo con Frederick. Quiero decir... se aprende tanto con él».

En esta actividad de aprendizaje no puede faltar uno de los profesionales más reconocibles de un museo, el guía, que con sus breves explicaciones va desgranando las nociones elementales ante el público entregado que le sigue por las salas. Unos, con docto conocimiento y una exquisita capacidad de comunicación, como el guía que explica las diferencias entre Murillo y Velázquez en Tierra y cielo (1941). Otros, con gran desparpajo pero nulos conocimientos, como ese Ignacio (Tony Leblanc) que en El pobre García (1961) se hace pasar por un verdadero guía del Prado: a unos pueblerinos deseosos de conocer el Museo les señala de Las meninas la capacidad del perro para posar quieto y de La rendición de Breda que recibe su nombre porque tiene lanzas a barullo. En clave o no de humor, estos ejemplos subrayan la importancia de la figura del guía en la educación de los visitantes y en la difusión de los contenidos de un museo. La tarea puede parecer sencilla, como le dice a Ignacio su amigo Paco (Manuel Gómez Bur) al explicarle en qué consiste el trabajo: «Este hombre -señala a un guía- tiene el empleo de guía. Para que lo entiendas. Su obligación es explicar el museo por dentro, mejor dicho, la historia de los cuadros». Lo que no le dijo es que para explicar «esa historia» son necesarios unos conocimientos especializados a cargo de un verdadero profesional.

\section{Un escenario contenedor de la excelencia}

El museo es un microcosmos de la actividad humana y ofrece, en una selección coherente y necesaria, una muestra representativa de los materiales y objetos más significativos. Es en esa selección donde se produce una criba por la excelencia, pues un museo debe albergar las obras más relevantes, como señala el narrador de Montparnasse 19 (1958) cuando al inicio del film explica que «hoy, todos los museos del mundo y los grandes coleccionistas se disputan los cuadros de Modigliani. Cada una de sus obras vale decenas de millones». Este compendio de obras únicas y originales hace al museo muy atractivo para un público que desea verlas con sus propios ojos. José Ruiz, profesor de dibujo y padre de Picasso, no quiere que este pierda la oportunidad de ver las grandes obras del Museo del Prado cuando paran en Madrid en tránsito desde A Coruña (El joven Picasso; 1992). Ambos acceden a la gran sala central del museo y la observan con suma satisfacción: «Tenemos muy poco tiempo. Apenas una hora. Y hay tanto que ver. El tren para Málaga sale a las tres», le dice el padre. «Velázquez antes que nadie -comenta el muchacho- y El Greco», quedando impresionado el futuro pintor al estar por vez primera frente a las obras de estos maestros.

Esta excelencia, aceptada de forma general por la sociedad, puede ocultar inercias y falta de espíritu crítico. Cuando Toulouse-Lautrec describe al Louvre como «un cementerio» (Moulin Rouge, 1952), los pintores presentes en la tertulia le reprochan su comentario al entender que no puede calificarse como tal un lugar que alberga obras como La Gioconda. Uno de ellos, Anquetin, comienza a alabarla: «Ah, la Mona Lisa, lo más grandioso que se ha pintado en el mundo. Ahora me pondría de rodillas ante el divino Leonardo para darle las gracias». «¿Cómo sabes que es lo más grandioso? ¿Y 


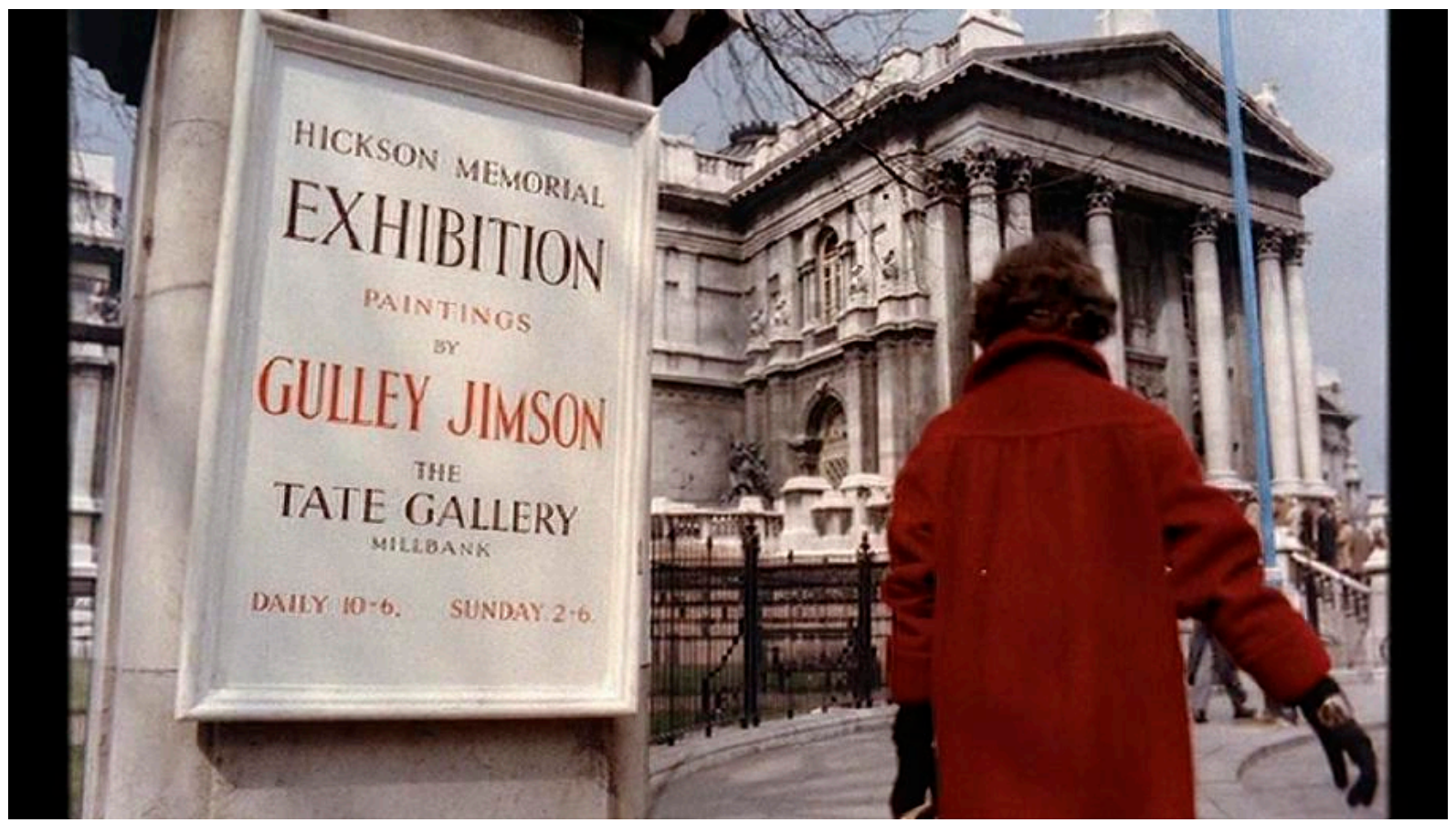

Cartel de la exposición de Gulley Jimson ante las puertas de la Tate Gallery, en The Horse’s Mouth (1958). Fotograma: Knightsbridge Films.

cómo sabes que lo pintó Leonardo?», le contesta Toulouse-Lautrec. Aquel le responde: «¿Qué cómo lo sé? Porque lo siento. Lo siento aquí, en mi corazón». Y Toulouse-Lautrec remata:

Yo siento que eres un imponente asno aunque aparentes otra cosa. (...) ... solo hay un medio de que sepas que la pintó Leonardo, por la chapita que has visto en el marco, y eso es lo que reverenciáis. Un nombre grabado en latón.

A pesar del comentario de Toulouse-Lautrec criticando el culto al nombre y a la fama (esa placa de latón), que para un artista alguna de sus obras termine expuesta en un museo significa su consagración, y así se lo hace saber el conde de Toulouse-Lautrec a su hijo Henri en el film Moulin Rouge (1952). Estando el pintor en su lecho de muerte, su padre intenta reconciliarse con él tras una vida de distanciamiento y rechazo:

¿Puedes oírme, Henri? (Sostiene en sus manos una carta.) Escucha. Es de Maurice Joyant. Es- cucha. El Louvre ha aceptado la colección Camondo. Eres el único artista a quien en vida se ha concedido tal honor. ¿Me has oído, Henri? El Louvre ha aceptado tus cuadros. He estado ciego, perdóname, no supe comprenderte.

Solo unos pocos, los grandes maestros, han logrado esta consagración, que otros muchos persiguen desorientados, como el pintor Rick Todd (Dean Martin) de Artists and Models (1955), quien cree que el éxito y la fama están garantizados si uno vive en una ciudad volcada en las artes: «Vinimos a Nueva York -le dice a su amigo Eugene Fullstack (Jerry Lewis) mientras le enseña una de sus pinturas- para ganar dinero y poder estudiar. $Y$ convertirme en un pintor famoso. Para que colgaran mis cuadros en las galerías de arte y en los museos».

No solo que un cuadro cuelgue de las paredes de un gran museo es un signo de consagración, también lo es que a un artista le dediquen una exposición y que esta sea un éxito. Así le 
ocurre, en el cénit de su carrera, al Francis Bacon de Love is the Devil (1998) y también al Gulley Jimson (Alec Guinness) de The Horse's Mouth (1958), un estrafalario, independiente y paupérrimo pintor que acaba triunfando en Londres a la muerte de uno de los coleccionistas de sus obras. Este coleccionista ha legado toda su colección al estado y ello posibilita la organización de una exposición retrospectiva de Jimson en la Tate Gallery Millbank. Los coleccionistas ya habían reconocido su talento, pero ahora le llega el turno al gran público, que formará grandes colas a las puertas de la exposición para admirar sus cuadros. Colas infinitas que convierten al museo en un notario de la confirmación pública de todo gran artista.

Ser un crisol de excelencias hace del museo un imán, un espacio de peregrinaje para otros artistas que acuden a sus salas para admirar las obras de los grandes maestros y aprender de ellos. De noche y a escondidas acude al Louvre la joven dibujante Michèle (Juliette Binoche) en Les amants du Pont-Neuf(1991) para observar, a la luz de una vela, los claroscuros de Rembrandt antes de que su progresiva ceguera se lo impida. Y a este mismo museo, en Moulin Rouge (1952), pese a considerarlo un cementerio de obras de arte, acude el pintor Toulouse-Lautrec con la joven Myriamme, de la que se ha enamorado, para mostrarle y explicarle la belleza de una obra inmortal como la Venus de Milo:

Es tan hermosa que olvidamos su edad... Hasta el fin de los tiempos los hombres intentarán penetrar el misterio de su perfección, pero no conseguirán descifrarlo. No es natural la sencillez de estas obras. Por qué había de serlo. La vida misma es compleja...

Unas obras insignes que confieren al museo una exclusividad y crean en torno a él una imagen de prestigio, que le permite erigirse en un escenario privilegiado para acontecimientos sociales y mediáticos de gran impacto. La serie
Lupin (2021), por ejemplo, se inicia en el Museo del Louvre, donde va a efectuarse la subasta de un valioso collar de diamantes, evento que atrae a coleccionistas y medios de comunicación de todo el mundo. En este sentido, el museo se convierte en el emblema y seña de identidad de una ciudad, como ocurre en muchos de los films ambientados en urbes (París, Nueva York, Londres, etc.), en cuyas secuencias iniciales de presentación no faltan, entre las imágenes de sus calles y de sus monumentos, las vistas de alguno de sus museos más reconocidos. La secuencia inicial de An American in Paris (1951), en la que el pintor Jerry Mulligan (Gene Kelly) explica en voz en off las razones por las cuales ha permanecido en París tras participar en la Segunda Guerra Mundial, muestra una sucesión de diferentes vistas de la ciudad (Plaza de la Concordia, la Ópera, el Sena, puente de Alejandro III...), en la que no falta una panorámica del antiguo palacio de las Tullerías, sede del Museo del Louvre. En este tipo de secuencias no se habla ni se describe el Museo ni sus contenidos, ni es necesario mencionar su nombre como tampoco se mencionan los de otros monumentos. Su propia imagen lo identifica y su presencia engrandece la imagen de la ciudad que lo acoge y asocia a ella su existencia, en una simbiosis perfecta de grandeur y prestigio sociocultural.

Si durante la edad media la catedral se impuso al monasterio y se convirtió en un símbolo de la urbe -señala Daniel Cid Moragas-, hoy los peregrinajes turísticos tienen como principal destino los museos. De hecho, estos se han convertido en emblemas de las nuevas ciudades como en su tiempo lo fueron las catedrales» (Cid Moragas, 2000).

Como institución que conserva y expone los más grandes logros de las civilizaciones, sus colecciones deben ser protegidas no solo de los ladrones, sino también de los avatares 


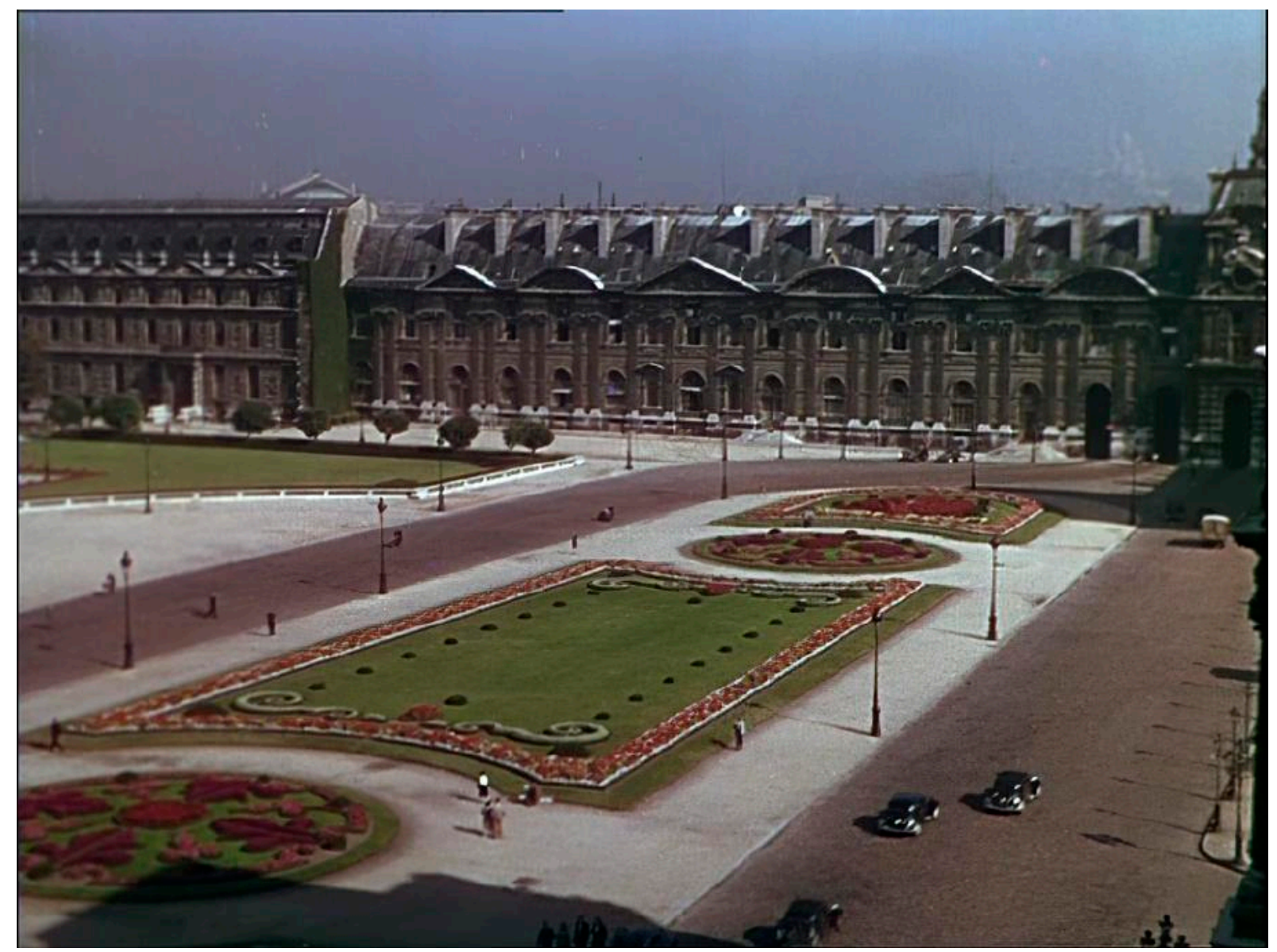

Imagen exterior del Louvre en la secuencia inicial de An American in Paris (1951). Fotograma: Metro-Goldwyn-Mayer.

de la historia, como guerras o desastres naturales. Así, la salvaguarda durante la Segunda Guerra Mundial de los fondos del Louvre por Jacques Jaujard es recordada en Francofonia (2015), y otro de los más ejemplares procesos de salvamento de obras de arte, como fue la evacuación de los cuadros del Museo del Prado durante la guerra civil española, es recreado en La hora de los valientes (1998) y en un episodio-La memoria del tiempo (2020)- de la serie El Ministerio del Tiempo. En la serie, aunque el tema central no es la evacuación, sino el imaginado intercambio entre Las meninas y $E l$ Guernica, la trama da pie, al retroceder hasta 1936, a explicar cómo se produjo esa evacuación, cómo eran protegidas las obras para su traslado y cómo estas eran cargadas en camiones para su posterior traslado a Valencia. En el film, el argumento se centra en el salvamento por unos civiles del autorretrato de Goya (Gimeno Ugalde, 2003). Un joven vigilante del Prado, Manuel (Gabino Diego), encuentra perdido el cuadro del pintor mientras es evacuado el Museo y para evitar su destrucción lo guarda en su casa con el propósito de devolverlo cuando termine el conflicto. Su protección no será fácil, pues deberá luchar contra fascistas y marchantes que codician la obra y contra la pobreza de su entorno familiar. Una tía del joven se pregunta, presumiendo el incalculable valor de la obra, si no podrían vender el cuadro para aliviar su situación: «¿Os habéis puesto a 


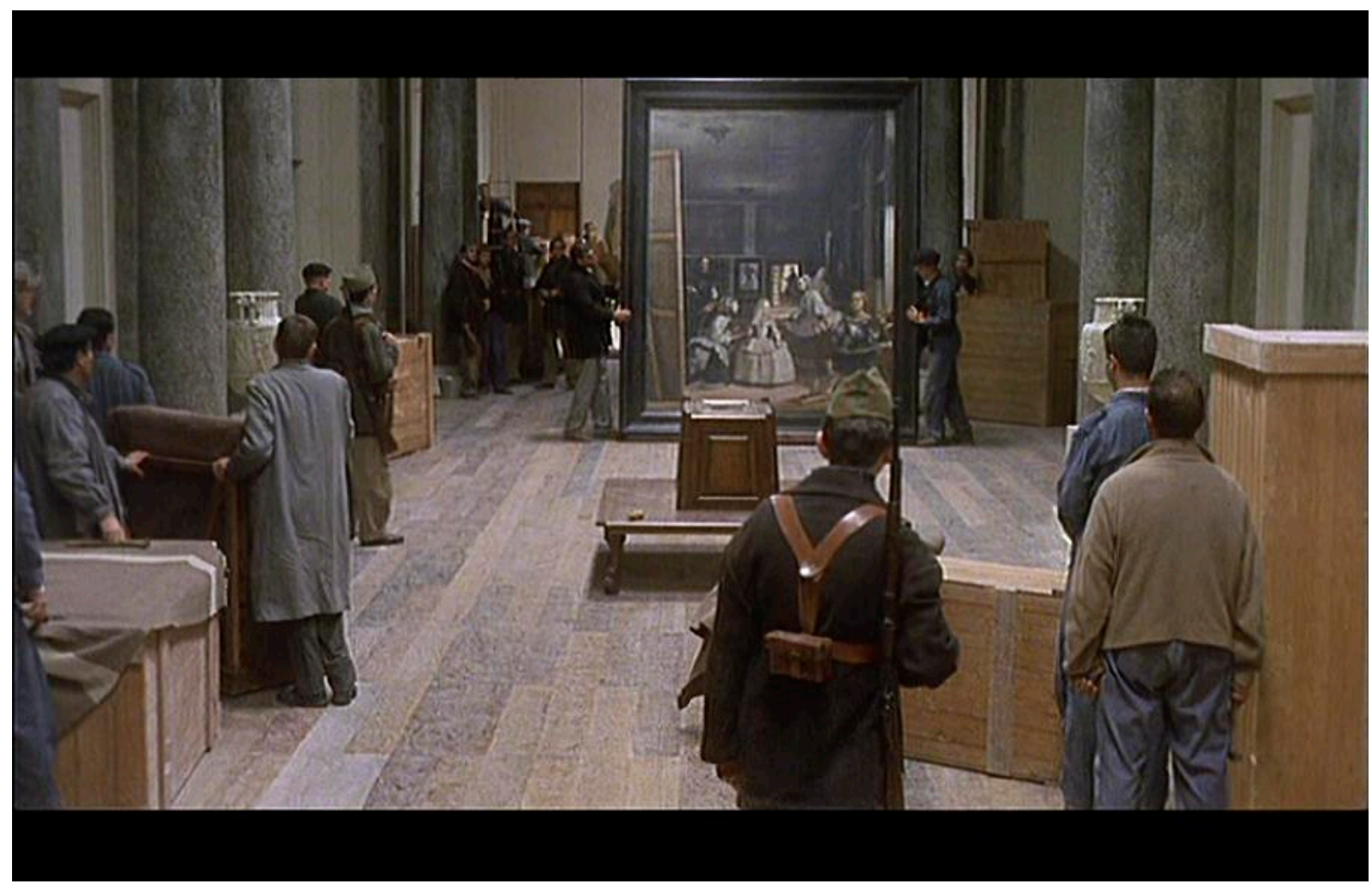

Evacuación del Museo del Prado durante la Guerra Civil en La hora de los valientes (1998). Fotograma: Enrique Cerezo PC.

pensar lo que nosotros podríamos hacer con todos esos millones?».

En esta serie de ejemplos, el cine no ha hecho sino subrayar dos de las funciones destacadas que la sociedad y el público atribuyen a un museo: la selección y exposición de los objetos más representativos de una colección, así como su preservación y protección. Aunque sin profundizar en ellos, ámbito que corresponde al terreno más profesional de conservadores, gestores y restauradores.

\section{Un escenario para las actividades de ladro- nes y falsificadores}

Un lugar para la excelencia alberga obras únicas y, como tales, verdaderos tesoros de la Humanidad, como intenta explicar Toulouse-Lautrec (Moulin Rouge, 1952) a otra de sus amantes, Marie Charlet, cuando esta le pregunta «cuán- to puede valer un cuadro». «Depende de quién lo haya pintado», responde el pintor y añade: «Hace unos 300 años un tal Da Vinci pintó el retrato de una mujer. No le gustó al marido y se negó a pagarlo. Actualmente el cuadro está en el Louvre y no hay en el mundo quien posea dinero suficiente para comprarlo». El hecho de que los museos alberguen obras de incalculable valor les convierte, tanto en la realidad (Díaz, 2020) como en la ficción cinematográfica, en un espacio idóneo para la codicia de coleccionistas y la intervención de expertos ladrones. Estos han de explotar su ingenio y sus habilidades para sortear los sofisticados mecanismos de protección de las obras y planificar sus sustracciones. Los films sobre robos en museos suponen prácticamente un subgénero del cine de atracos y una de las más valiosas aportaciones cinematográficas a la imagen colectiva del museo como un centro inexpugnable, pero vul- 
nerable, ante las maquinaciones de ingeniosos amantes de lo ajeno.

En Topkapi (1964), el grupo de ladrones que intenta robar la daga del sultán Mahmud I desde los techos del museo turco de Topkapi ha de sortear un sofisticado sistema de seguridad, y en El robo más grande jamás contado (2002) será un conjunto de personajes de lo más friki, al mando de Santos (Antonio Resines), el que intente robar el Guernica del Museo Nacional Centro de Arte Reina Sofia. Ambos films construyen su trama alrededor de la constitución del grupo de ladrones, el diseño del plan de robo y su minuciosa ejecución. Menos atención en su trama al hecho delictivo dedican los films How to Steal a Million (1966) o The Thomas Crown Affair (1999) pues, aunque sus historias describen el proceso de la sustracción, no centran todo su argumento en ello. En el primero de estos films, Nicole (Audrey Hepburn), la hija de un falsificador, propone a un ladrón de guante blanco (Simon Dermott, interpretado por Peter O’Toole) robar de una exposición temporal en París una Venus de Cellini para que no se descubra que es una falsificación. Ambos urden un plan para robar la estatuilla, permaneciendo escondidos en un trastero del museo hasta que este cierre sus puertas al público, y es entonces cuando Simon debe burlar los sistemas de seguridad que protegen la estatuilla y sustraerla. En el segundo, un elegante multimillonario, Thomas Crown, roba un atardecer de Monet de un museo de Nueva York (The Thomas Crown Affair; 1999) para retar, en un juego de inteligencia y divertimento, a los miembros de seguridad. Y aunque el argumento sigue por otros derroteros describiendo su vida de ocio y placeres, el tramo final del film se centra en cómo el multimillonario decide devolver la obra al museo sin ser descubierto. Para ello idea una inteligente estratagema ayudado por decenas de individuos disfrazados de igual manera que un personaje de un cuadro del pintor Magritte
-El hijo del hombre (1964)-, sembrando el caos y la confusión entre los responsables de la seguridad. El espectador descubrirá finalmente, en un inolvidable giro de guion, que la obra se hallaba oculta bajo una acuarela, la cual se desvanece cuando la alarma activa las medidas contraincendios y la pintura se va diluyendo, dejando ver por debajo la «obra robada» pintada al óleo.

Otro ladrón, Jimmy Bourne (Rex Harrison), aliado con un copista, intenta sustraer del Museo del Prado el cuadro El 2 de mayo de Francisco de Goya en The Happy Thieves (1961). La idea es sencilla. El copista irá a diario al Prado a realizar las copias de dos cuadros de Goya. Estas copias le permitirán ocultar el original de El 2 de mayo, que simultáneamente está copiando a tamaño real fuera del Museo a partir de fotografías. El día del robo, el 15 de mayo en Madrid, será fácil intercambiar el original por su réplica, ocultándolo al salir bajo esas dos copias que ha ido realizando, pues se supone que los vigilantes estarán entretenidos con la noticia bomba del día: un afamado torero ha sido cogido en la Plaza de Las Ventas.

Estos robos imaginados por guionistas y directores no están muy lejos de una realidad que el cine también ha recordado narrando algunos robos reales que causaron sensación en la opinión pública. Entre ellos, el de la Gioconda, en 1911, del cual fueron acusados el poeta Apollinaire y el pintor Picasso, según cuenta Colomo en La banda Picasso (2012) o, en 1985, el de varias piezas prehispánicas del Museo Nacional de Antropología de México a cargo de dos ladrones inexpertos, como cuenta Alonso Ruizpalacios en su film Museo (2018), donde lo más difícil no fue la sustracción de las piezas, sino intentar colocarlas en el mundo de los coleccionistas.

Como ha desmentido en algún momento la historia, no es oro todo lo que reluce, y el museo puede ser también un lugar para 


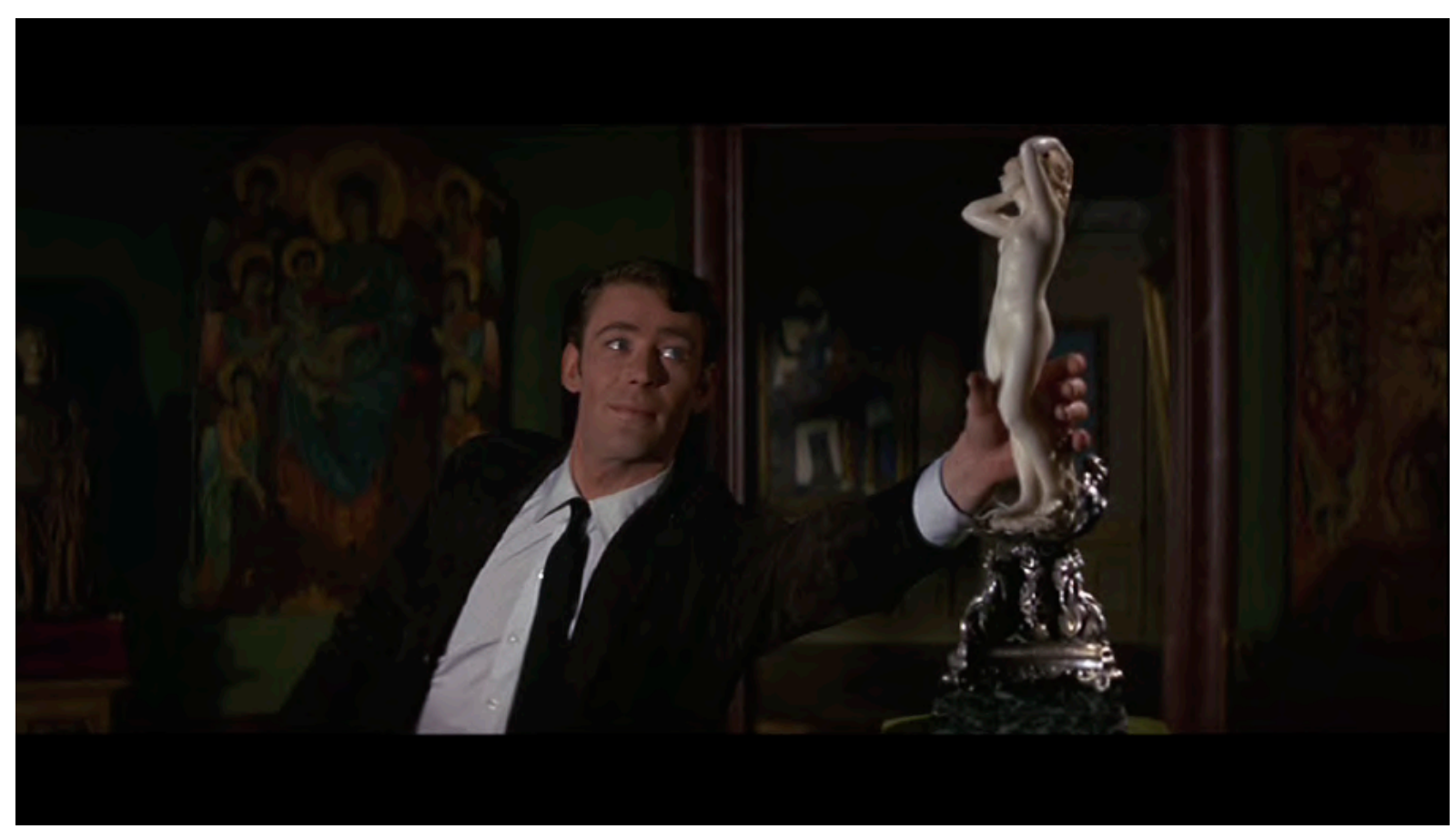

Simon Dermott (Peter O’Toole) sustrayendo la Venus de Cellini del museo tras haber burlado las medidas de seguridad, en How to Steal a Million (1966). Fotograma: 20th Century Fox.

las sospechas justificadas. En How to Steal a Million (1966), un museo parisino se desvive por exhibir en sus salas la afamada «Venus de Cellini» (que no es original, sino una falsificación contemporánea), ya que con ella en sus vitrinas la institución ganará en prestigio y aumentará el número de sus visitantes. El director del museo, Monsieur Grammont (Fernand Gravey), acude a casa de su propietario (un falsificador de pinturas hijo del escultor que falsificó la estatuilla):

La recordaba como una obra de arte. Pero es algo más. Amigo mío, le expreso mi gratitud personal y la del museo por su generoso préstamo y también la de toda Francia por no haber permitido que el tesoro abandonara el país. Sé las ofertas que habrá recibido y lo tentadoras que debieron ser.

La obra acaba siendo expuesta, para gran admiración de su propietario, que lo interpreta como un triunfo personal:
Ah, Nicole, pequeña mía. (Habla con su hija.) Lástima que te perdieras la inauguración. Nuestra Venus fue un éxito sensacional. No te imaginas la gente, miles de personas, fotógrafos de todas nacionalidades, y nuestra Venus de Cellini el centro de la exposición...

Resulta toda una satisfacción para un falsificador poder exponer una «obra falsa» en un museo, engañando a críticos, expertos y público. Y una desazón e inseguridad para el mundo del arte, porque ¿cuántas obras falsas, como esta Venus, habrán terminado colgadas en las paredes de los museos? (Aranguren, 2011). Al menos, las falsificaciones de Matisse, Cézanne y Modigliani del pintor Nick Hart si se diera por verdadera la historia inventada por Alan Rudolph en The Moderns (1988). En este film, un coleccionista encarga unas copias a Hart, pero por azares del destino, los originales son destruidos erróneamente y sus copias son tenidas por verdaderas. Estas terminan colgando 


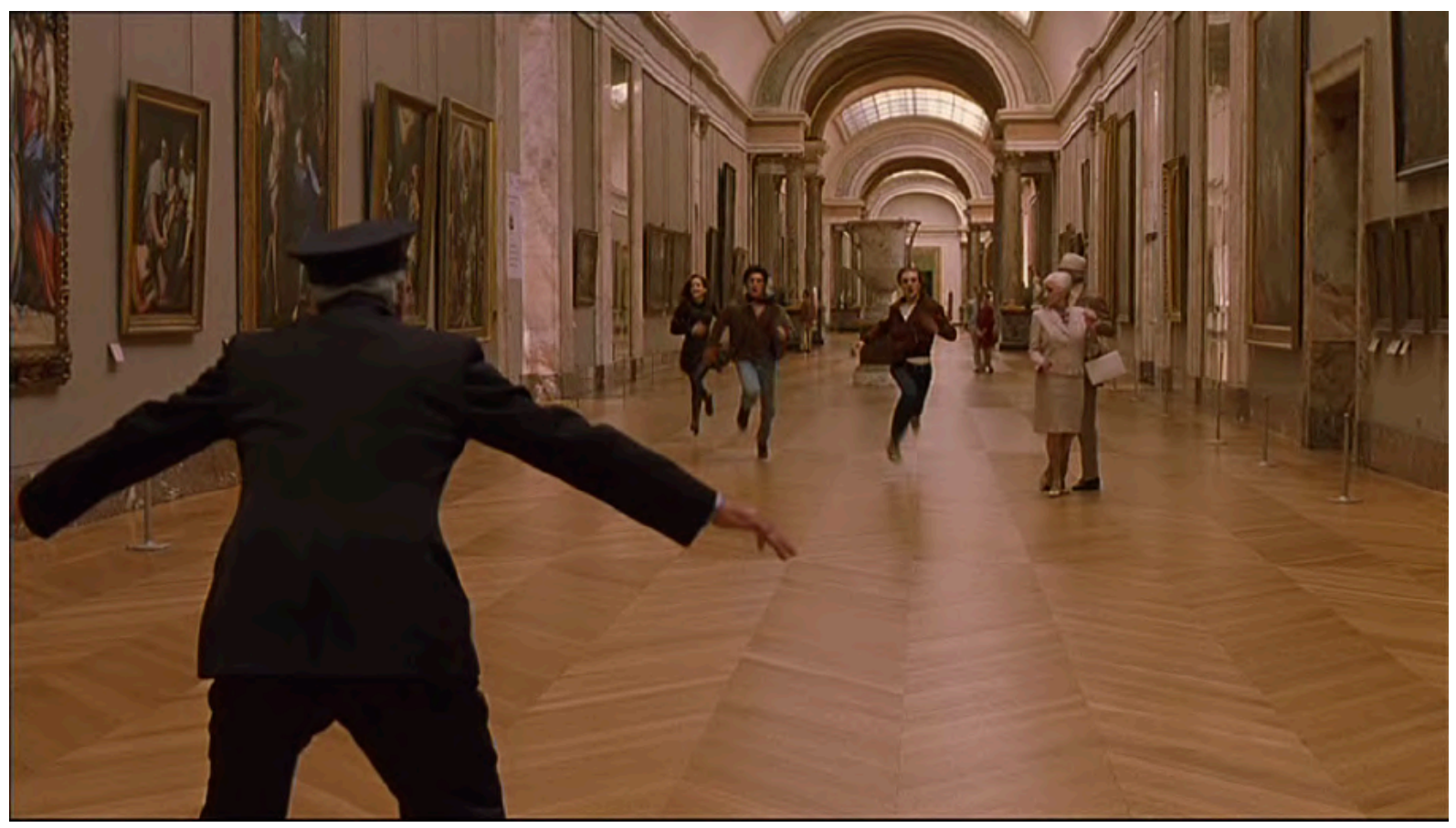

Un vigilante intentando detener a los tres protagonistas de The Dreamers (2003), emulando la carrera de los intérpretes de Bande à part (1964). Fotograma: Recorded Picture Company (RPC).

en las salas de un museo neoyorquino, como puede contemplar el falsificador, para su regocijo, en la secuencia final del film. Y quizás puedan ser muchas más si se dan por ciertas las declaraciones del célebre falsificador Elmyr de Hory en el film-ensayo de Orson Welles Vérités et mensonges (1973), cuando afirma que vendió diferentes obras a grandes museos del mundo. Cruel paradoja la de estos falsificadores, halagados por la maestría de sus copias pero a su vez ignorados, ya que sus obras son expuestas no con rúbrica propia, sino bajo la firma de consagrados artistas.

\section{Un centro de trabajo}

Una pléyade de profesionales trabaja entre las cuatro paredes de un museo, pero de todos ellos son los copistas los que parecen más interesantes para el cine, pues a su habitual presencia en las salas se añade su maestría en la copia fidedigna de los cuadros expuestos. Se pueden ver copistas, en un intento por recrear de forma realista las salas de un museo, en la breve visita que un Picasso adolescente hace al Prado en El joven Picasso (1992) y también en el Louvre que recorren a toda prisa los protagonistas de Bande à part (1964). Estas menciones indican que no pueden entenderse las salas de un museo sin estos profesionales, que en algunos films llegan a adquirir mayor protagonismo. En Tierra $y$ cielo (1941), de Eusebio Fernández Ardavín, la joven Clara (Maruchi Fresno) se dedica a copiar una «Inmaculada» de Murillo en el Museo del Prado. La muchacha se enamora de un joven que oculta un oscuro pasado $y$, en sus dudas sobre su enamoramiento, algunos personajes femeninos de célebres cuadros del Museo (María Magdalena de Ribera, Santa Casilda de Zurbarán, la Inmaculada de Murillo...) cobran vida en un sueño de la protagonista y le aconsejan que no renuncie a su amor. No ha sido infrecuente que 
en el cine obras inanimadas cobren vida, pero en este caso el uso de esta licencia ratifica la importancia de las obras de arte de un museo, identifica cuáles eran (a juicio de la época) algunos de los cuadros con personajes femeninos más significativos del Prado, y a su vez recalca la indisociable interacción entre sus profesionales (copistas) y sus objetos de atención (los cuadros).

El objetivo de un buen copista es imitar fielmente, aunque en tamaño más reducido, una obra original expuesta en las salas. Su trabajo es público, pues pinta ante los visitantes y, por tanto, está sujeto a sus posibles comentarios, que normalmente son de alabanza y admiración ante su destreza. Uno de estos visitantes, que terminará por convertirse en ese novio de oscuro pasado de la copista Clara, de Tierra y cielo (1941), al verla trabajar en el Prado comenta que su copia de la Inmaculada «es admirable. (...) No parece realmente una copia, sino la imagen original reflejada en un espejo. (...) Hace unos días que la veo trabajar y me cautiva su destreza, su gusto». Tiempo después, otro visitante quedará así mismo impactado por la calidad de la copia y deseará adquirirla al instante: «Es perfecta. El propio Murillo la aplaudiría». Comentarios que muestran la positiva imagen que el cine ofrece de estos profesionales que, aunque no pertenecen al museo, forman parte de su paisaje habitual.

Este perfeccionismo de los copistas no solo impresiona al público, sino también a codiciados timadores, como el ladrón Jimmy Bourne de The Happy Thieves (1961), quien contrata al pintor Jean-Marie Calbert (Joseph Wiseman) para que le ayude en el gran robo del cuadro El 2 de mayo de Goya. «No parece muy fácil -le explica Jimmy- pero es un reto... Vale más de un millón de dólares». Y el copista acepta con la esperanza de salir así de la ruina, aunque su trabajo llegue a resultarle tedioso:

Tres largas semanas. Me han obligado a emplear tres semanas para copiar tres Goyas en un lien- zo. Hubiera podido iluminar la Biblia de Gutenberg, pintar a mano 400 corbatas y me habría sobrado tiempo para cuatro Grecos. Los vigilantes ya casi son como de la familia.

Son precisamente los vigilantes otro de los colectivos profesionales más cinematografiados, quizás porque junto con guías y copistas son los trabajadores más expuestos a las miradas de los visitantes y parecen indisolublemente unidos a la imagen pública de un museo. El más famoso de todos ellos es Larry Daley (Ben Stiller), contratado como guardia de seguridad nocturno en el Museo de Historia Natural de Nueva York en el film Night at the Museum (2006). En este film y en sus dos secuelas (Night at the Museum: Battle of the Smithsonian, 2009 y Night at the Museum: Secret of the Tomb, 2014) el vigilante es protagonista absoluto de los films e imprescindible profesional en el mantenimiento del orden en unas salas que cobran vida por la noche. Pero en otros films, como Bande à part (1964) y The Dreamers (2003), donde aparecen recriminando las carreras de sus protagonistas, o en Sunshine on Leith (2014), donde bailan y cantan por las salas -en una licencia cinematográfica- mientras conversan sobre sus vidas, son tan solo personajes de figuración que dan ambientación al museo. En unos casos $\mathrm{u}$ otros, estos personajes inciden en la representación del museo como un lugar donde debe reinar la seguridad, la tranquilidad y el silencio.

Pero, por lo general, lo que no conoce el público es que existe otro personal, al que no se ve habitualmente cuando se visita un museo, que también trabaja en él, que tiene asignados determinados cometidos -investigación, restauración, difusión, gestión, mantenimiento, seguridad, biblioteca- y que es responsable de que el centro funcione como un engranaje sincronizado para poner a disposición del visitante los resultados de su trabajo. (Jesús Urrea, 2004).

Todo un mundo que raramente aparece en los films, pero que en ocasiones llega a vislum- 


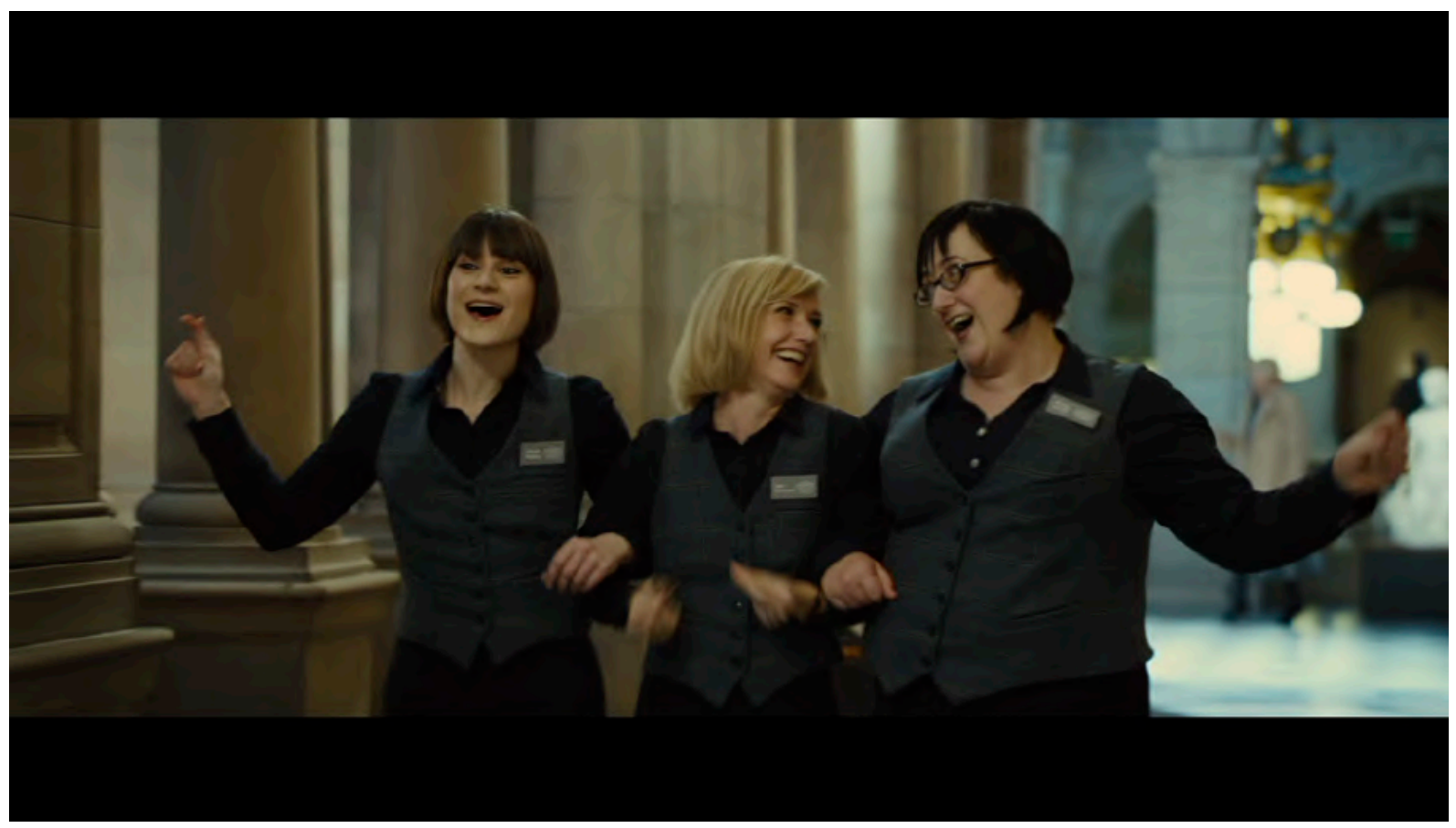

Vigilantes de sala, bailando y musicalizando sus problemas diarios, en Sunshine on Leith (2014). Fotograma: Black Camel Pictures y DNA Films.

brarse en películas como House of Wax (1953), donde vemos al escultor en una de las dependencias del museo preparar en arcilla los modelos de sus figuras de cera; como en Nocturnal Animals (2016), donde asistimos en una sala blanca, aséptica e impoluta a una reunión de la dirección del museo para tratar temas del personal; o en The Square (2017), donde desde los despachos de sus gestores se diseñan exposiciones, presentaciones, ruedas de prensa y actos sociales que muestran la vida de un museo más allá de sus salas de exposición.

En la actualidad, un museo es todo esto y mucho más, como señala el director de cine Östlund en su film The Square (2017). Pero un museo sin público no es nada, y por eso en el museo contratan a una agencia de publicidad para que les ayude a atraer más visitantes a sus salas. Para conseguir esta atención de la sociedad parece que es necesario generar polémica, una polémica que llega a la opinión pública a través de una exposición de un simple cuadrado de neón en el patio central del museo. Tampoco puede concebirse un museo actual como una institución encerrada en sí misma. Esta debe abrirse a la sociedad (The Square, 2017) a través de sus exposiciones temporales y a través de eventos públicos, como ruedas de prensa (a veces arruinadas por un espectador con síndrome de Tourette), y eventos sociales, como esa cena de gala para benefactores, promotores y amigos del museo, que se inicia como un divertimento con la performance de un actor haciendo de simio. El acto se convierte en provocación cuando el personaje del actor humilla a los asistentes y termina en drama cuando varios de los comensales terminan enfrentándose a él por su insultante comportamiento.

\section{Y un lugar para la imaginación}

El cine nos ha ofrecido situaciones verosímiles, que podrían no haber sido realidad o no haberse producido tal y como se narran (por 


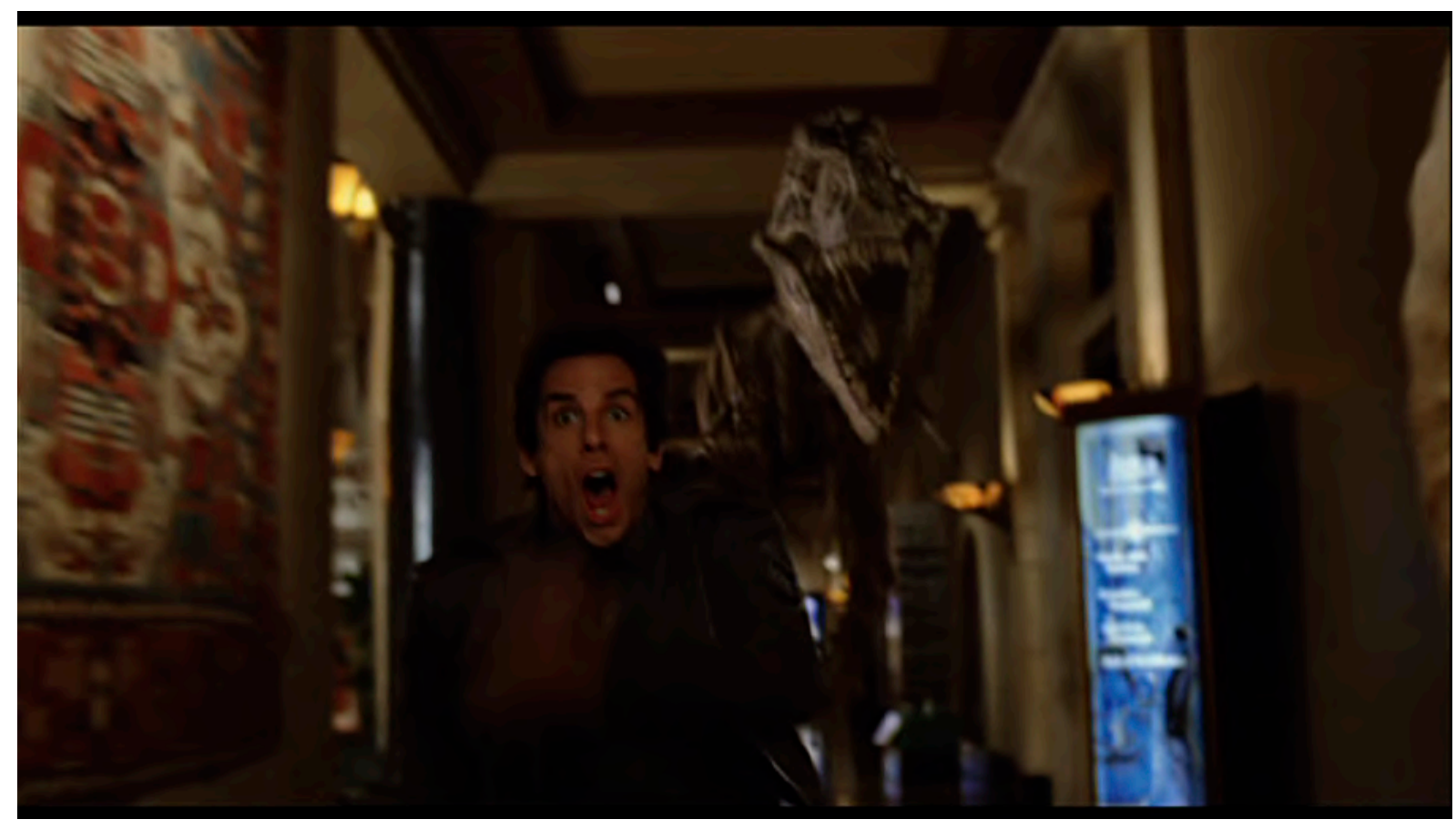

El vigilante nocturno Larry Daley corriendo delante del Tiranosaurio Rex en las salas del Museo de Historia Natural de Nueva York en Night at the Museum (2006). Fotograma: 20th Century Fox.

ejemplo, las visitas de Toulouse-Lautrec o de Henri Gaudier al Louvre) y ha creado personajes como el comisario jefe de The Square (2017), que bien puede responder al perfil de un gestor de un museo contemporáneo. Sin embargo, también ofrece historias ambientadas en museos que resultan completamente inverosímiles, pero que responden a la idea del cine como espectáculo y entretenimiento. En este marco habría que situar los tres films de la serie Noche en el museo. En ellos, por la magia del cine, los objetos inanimados del espacio museístico (animales disecados, estatuas y figuras de dioramas) cobran vida de noche, gracias a una tablilla de un antiguo faraón egipcio, y ofrecen al espectador divertidas aventuras. Larry Daley, un padre divorciado que arrastra fama de fracasado, es contratado como vigilante nocturno en el Museo de Historia Natural de Nueva York en el primer film de la trilogía. Con este contrato laboral se propone rehacer su vida y demostrar a su exesposa e hijo que no es un inútil. La tarea no será fácil. Los anteriores vigilantes nocturnos, recién jubilados, le explican su trabajo como vigilante y le hacen una seria advertencia: «No dejar que nadie entre o salga». Larry se extraña ante tal aviso, pero cuando se encuentra solo, de noche en el museo, lo entenderá: todo cobra vida, desde el esqueleto de un Tiranosaurio Rex hasta un mono disecado, la estatua de Roosevelt a caballo o las figuras de vaqueros y romanos de los dioramas, junto a las de Atila o la india Sacajawea. El problema es que si alguno de ellos llegara a salir al exterior, se convertiría en polvo y se desintegraría. Larry debe, no solo evitar que estos personajes salgan del museo, sino poner orden para que a la mañana siguiente las salas recobren la normalidad propia de la institución. Esta serie viene a demostrar que los museos están muy alejados de esa imagen seria, y hasta un tanto aburrida, que de ellos puede tener buena parte de la sociedad. Incluso este tipo de films con- 
siguen contribuir a despertar el interés entre niños y adolescentes por los museos, resultando un importante reclamo publicitario (de hecho, las visitas al Smithsonian de Washington aumentaron después de la segunda película de esta serie, ambientada en dicho museo).

\section{Filmografía}

Blackmail (1929; Chantaje), de Alfred Hitchcock

Mystery of the Wax Museum (1933; Los crimenes del museo), de Michael Curtiz

Tierra y cielo (1941), de Eusebio Fernández Ardavín

An American in Paris (1951; Un americano en París), de Vincente Minnelli

Moulin Rouge (1952), de John Huston

House of Wax (1953; Los crímenes del museo de cera), de André de Toth

Artists and Models (1955; Artistas y modelos), de Frank Tashlin

Three Cases of Murder (1955; Tres casos de asesinato) Episodio The Picture (En el cuadro), de Wendy Toye

The Horse's Mouth (1958; Un genio anda suelto), de Ronald Neame

Montparnasse 19 (1958; Los amantes de Montparnasse), de Jacques Becker

Vertigo (1958; Vértigo. De entre los muertos), de Alfred Hitchcock

El pobre García (1961), de Tony Leblanc

The Happy Thieves (1961; Último chantaje), de George Marshall

Bande à part (1964, Banda aparte), de Jean-Luc Godard Topkapi (1964), de Jules Dassin

How to Steal a Million (1966; Cómo robar un millón y...), de William Wyler

To Sir, with Love (1967; Rebelión en las aulas), de James Clavell

Fellini-Satyricon (1969; El Satiricón de Fellini), de Federico Fellini

Savage Messiah (1972; El Mesías salvaje), de Ken Russell

Vérités et mensonges (1973; Fraude), de Orson Welles

Yo soy fulana de tal (1975), de Pedro Lazaga

Hannah and Her Sisters (1986; Hannah y sus hermanas), de Woody Allen

The Moderns (1988; Los modernos), de Alan Rudolph

Vincent and Theo (1990; Vincent $y$ Theo), de Robert Altman
Les amants du Pont-Neuf (1991; Los amantes del PontNeuf), de Leos Carax

El joven Picasso (1992), de Juan Antonio Bardem

La hora de los valientes (1998), de Antonio Mercero

Love is te Devil (1998; El amor es el demonio), de John Maybury

The Thomas Crown Affair (1999; El caso Thomas Crown), de John McTiernan

El robo más grade jamás contado (2002), de Daniel Monzón

Russkij Kovcheg (2002; El arca rusa), de Aleksandr Sokúrov

The Dreamers (2003; Soñadores), de Bernardo Bertolucci

Mona Lisa Smile (2003; La sonrisa de Mona Lisa), de Mike Newell

Night at the Museum (2006; Noche en el museo), de Shawn Levy

Night at the Museum: Battle of the Smithsonian (2009; Noche en el museo 2), Shawn Levy

La banda Picasso (2012), de Fernando Colomo

National Gallery (2014), de Frederick Wiseman

Night at the Museum: Secret of the Tomb (2014; Noche en el museo: El secreto del faraón), de Shawn Levy

Sunshine on Leith (2014; Amanece en Edimburgo), de Dexter Fletcher

Francofonia (2015; Francofonía), de Aleksandr Sokúrov Nocturnal Animals (2016; Animales nocturnos), de Tom Ford

The Square (2017), de Ruben Östlund

Museo (2018), de Alonso Ruizpalacios

Episodio La memoria del tiempo, de la serie El Ministerio del Tiempo (2020), de Anaïs Pareto Onghena

Lupin (2021), de George Kay y François Uzan

\section{Bibliografía}

Almagro Gorbea, María Josefa (1988) «La utilidad de sustitutos y reproducciones en los museos», Boletín ANABAD, 3: 177-185.

Álvarez Domínguez, Pablo y Juan Rubén Benjumea Cobano (2011) «Aproximación al museo contemporáneo: entre el templo y el supermercado cultural», Arte y Políticas de Identidad, 5: 27-42. Disponible en https://revistas.um.es/reapi/article/ view/146201 [Fecha de consulta 15/02/2021] 
ArriagA, Amaia (2011) «Desarrollo del rol educativo del museo: narrativas y tendencias educativas», Revista Digital do Laboratório de Artes Visuais, 7: 1-23. Disponible en https://periodicos.ufsm.br/revislav/article/view/3070/2156 [Fecha de consulta $1 / 03 / 2021]$

Brown, Karen y François MaIresse (2018) «The definition of the Museum through its social role», $\mathrm{Cu}$ rator. The Museum Journal, 4: 525-539. Disponible en https://doi.org/10.1111/cura.12276 [Fecha de consulta 2/09/2020]

Caballero Zoreda, Luis (1980) «El museo: funciones, personal y su formación», Boletín ANABAD, 3: 377-385. Disponible en http://digital.csic.es/bitstream/10261/13858/1/965418.pdf [Fecha de consulta $2 / 09 / 2020]$

Carbonell, Eduard (2005) «Reflexiones en torno a los museos, hoy», Museos.es, 1: 12-21. Disponible en http://www.culturaydeporte.gob.es/dam/jcr:5bfa58b5-5877-455a-8fbf-6c7651c35788/s1-1entornoalmuseo.pdf [Fecha de consulta 13/03/2021]

Casas, Quim (2016) «El arte y el poder», Dirigido por, 467: 22-23.

- (2017) «Arte contemporáneo», Dirigido por, 482: 18-19.

Cid Moragas, Daniel (2000) «Museo y ciudad», Temes de disseny, 16: 101-105. Disponible en https://www.raco.cat/index.php/Temes/article/ view/29571/67947 [Fecha de consulta 13/03/2021]

DíAz, Montserrat (2020) «Los grandes robos de arte». Disponible en https://losgrandesrobosdearte.wordpress.com/category/robos-en-museos/ [Fecha de consulta 28/08/2020]

Falk, John H.; Dierking, Lynn D. y Susan Foutz (eds.) In Principle, in Practice: Museums as Learning Institutions. Lanham, Maryland: AltaMira Press.

Gimeno Ugalde, Esther (2011) «Cuadros en movimiento: la pintura en el cine. Relaciones intermediales en La hora de los valientes (Mercero 1998) y Te doy mis ojos (Bollaín 2003)». Olivar: revista de literatura y cultura españolas, 16: 215-240. Disponible en http://www.memoria.fahce.unlp.edu.ar/ art_revistas/pr.5129/pr.5129.pdf [Fecha de consulta $15 / 02 / 2021]$
Guasch, Anna Maria (2008) «Los museos y lo museal: el paso de la modernidad a la era de lo global», Calle 14, 2: 10-21. Disponible en https://revistas.udistrital.edu.co/index.php/c14/article/view/1236/1658 [Fecha de consulta 15/02/2021]

Iriondo Aranguren, Mikel (2011) «Copias del arte y arte de la copia», en Alcaraz, María José; CARRAsco, Matilde y Salvador Rubio (eds.) (2011) Art, Emotion and Value Proceedings of the 5th Mediterranean Congress of Aesthetics. Cartagena (Spain), 4th-8th July 2011, Cartagena: Universidad Politécnica de Cartagena, 239-251. Disponible en https://citeseerx.ist.psu.edu/viewdoc/download?doi $=10.1 \cdot 1.460 .6177 \&$ rep $=$ rep $1 \&$ type $=$ pdf $\#$ page $=240$ [Fecha de consulta 13/01/2021]

LAtorre, José María (2007) «El arca rusa», Dirigido por, 371: 93.

Le Genissel, Aurélien (2015) «Tres horas en el museo», Dirigido por, 453: 31.

LEón, Aurora (1988) El museo. Teoría, praxis y utopía, Madrid: Cátedra.

Urrea Fernández, Jesús «Las funciones del museo: Una línea de exposiciones», Museo.es, 0: 219-223. Disponible en http://www.culturaydeporte.gob.es/ dam/jcr:81af87c4-7ede-4388-b194-e081b7d4e918/ funcionesrev0.pdf [Fecha de consulta 29/08/2020]

VALDÉs SAGüÉs, Carmen (2008) «La divulgación, una función del museo». Museos.es, 4: 64-75. Disponible en http://www.culturaydeporte.gob.es/dam/ jcr:864e98ce-9d20-4d25-bf6b-eb43fb9503b2/desde-difusion-funcion-museo-c-valdes.pdf [Fecha de consulta 29/08/2020]

Recibido el 8 del 5 de 2021

Aceptado el 4 del 11 de 2021 BIBLID [2530-1330 (2021): 49-69] 


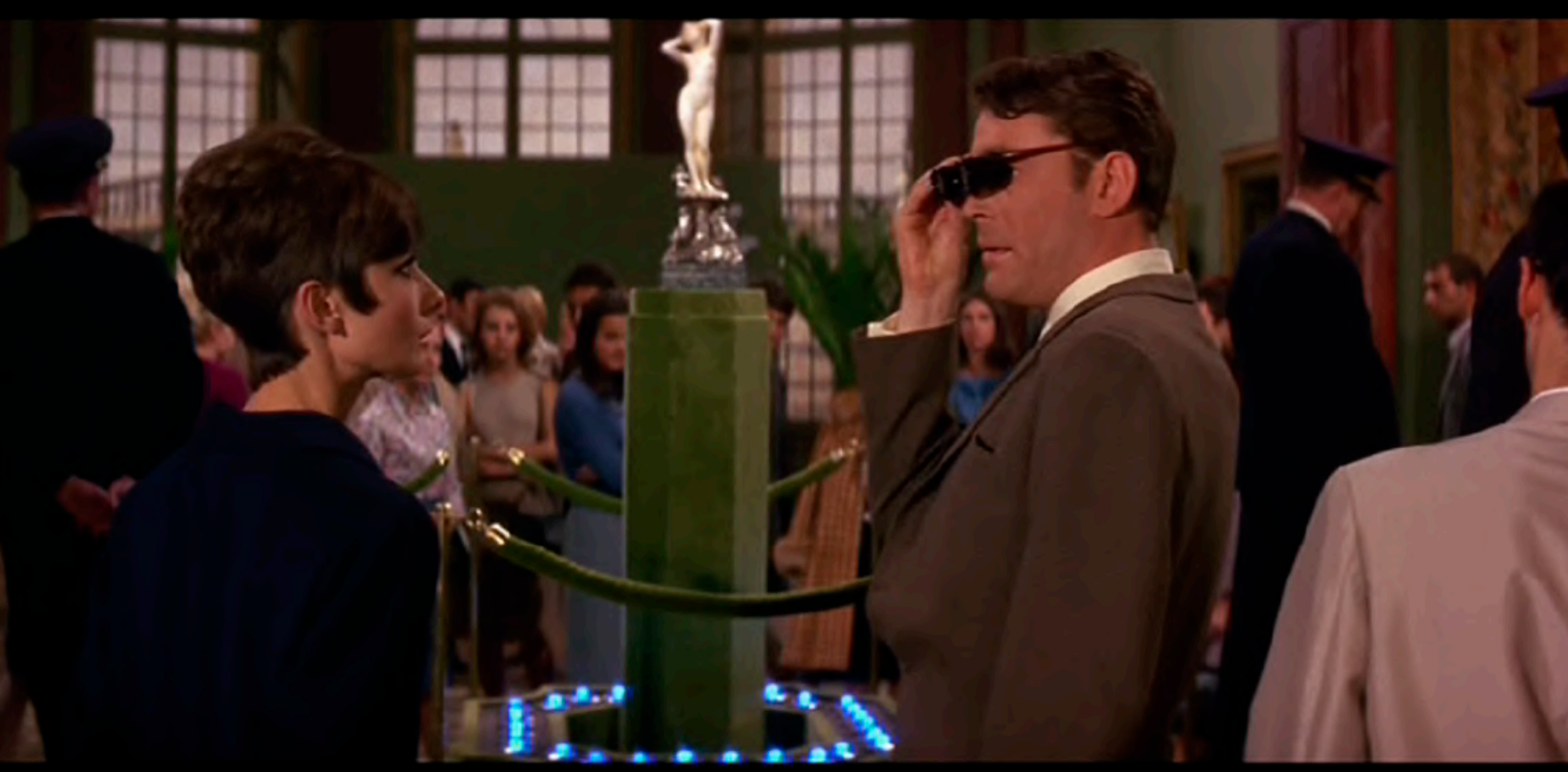

Simon Dermott (Peter O’Toole) y Nicole (Audrey Hepburn) estudiando en el terreno cómo sustraer la Venus de Cellini expuesta en el Museo, en How to Steal a Million (1966) Fotograma: 20th Century Fox 